\title{
Alkaline Earth Metal Aluminates as Catalysts for Imine Hydrogenation
}

Holger Elsen, Jens Langer, Michael Wiesinger, Sjoerd Harder*

Inorganic and organometallic chemistry, Friedrich-Alexander-Universität Erlangen-Nürnberg, Egerlandstraße 1, 91058 Erlangen, Germany.

Corresponding author: sjoerd.harder@fau.de

\section{Table of contents}

1. Selected NMR Spectra S2

2. Catalytic Imine Hydrogenation S11

3. Crystal Structure Determination $\quad$ S18

$\begin{array}{lll}\text { 4. DFT Calculations } & \text { S28 }\end{array}$

5. References $\quad$ S32 


\section{Selected NMR Spectra}

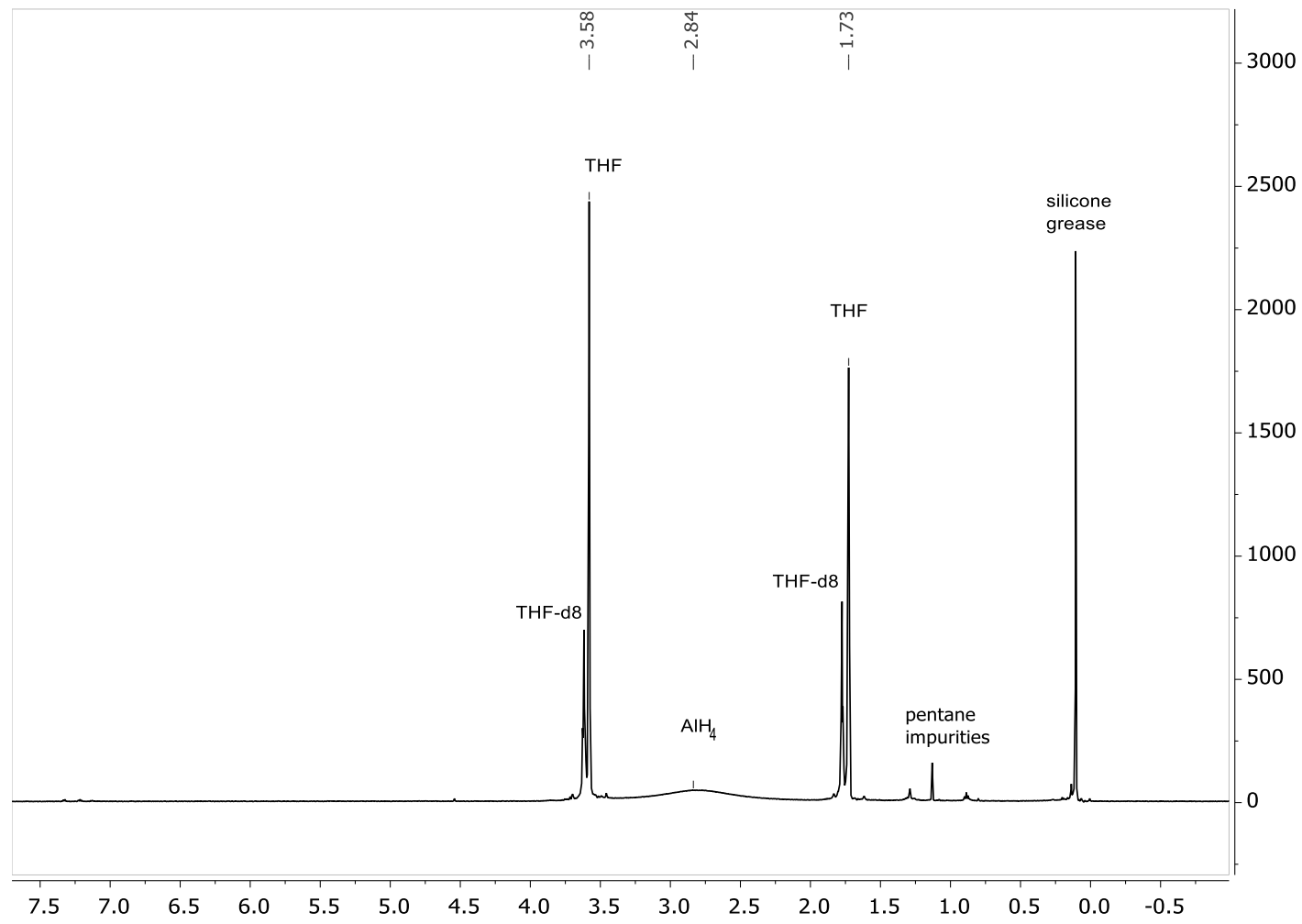

Fig. S1: ${ }^{1} \mathrm{H}-\mathrm{NMR}$ of $\mathrm{Mg}\left(\mathrm{AlH} \mathrm{H}_{4}\right)_{2} \cdot(\mathrm{THF})_{4}$ in THF-d8. The hydrides are broadened due to coupling with the ${ }^{27} \mathrm{Al}$ nucleus (2.25 - $3.50 \mathrm{ppm})$.

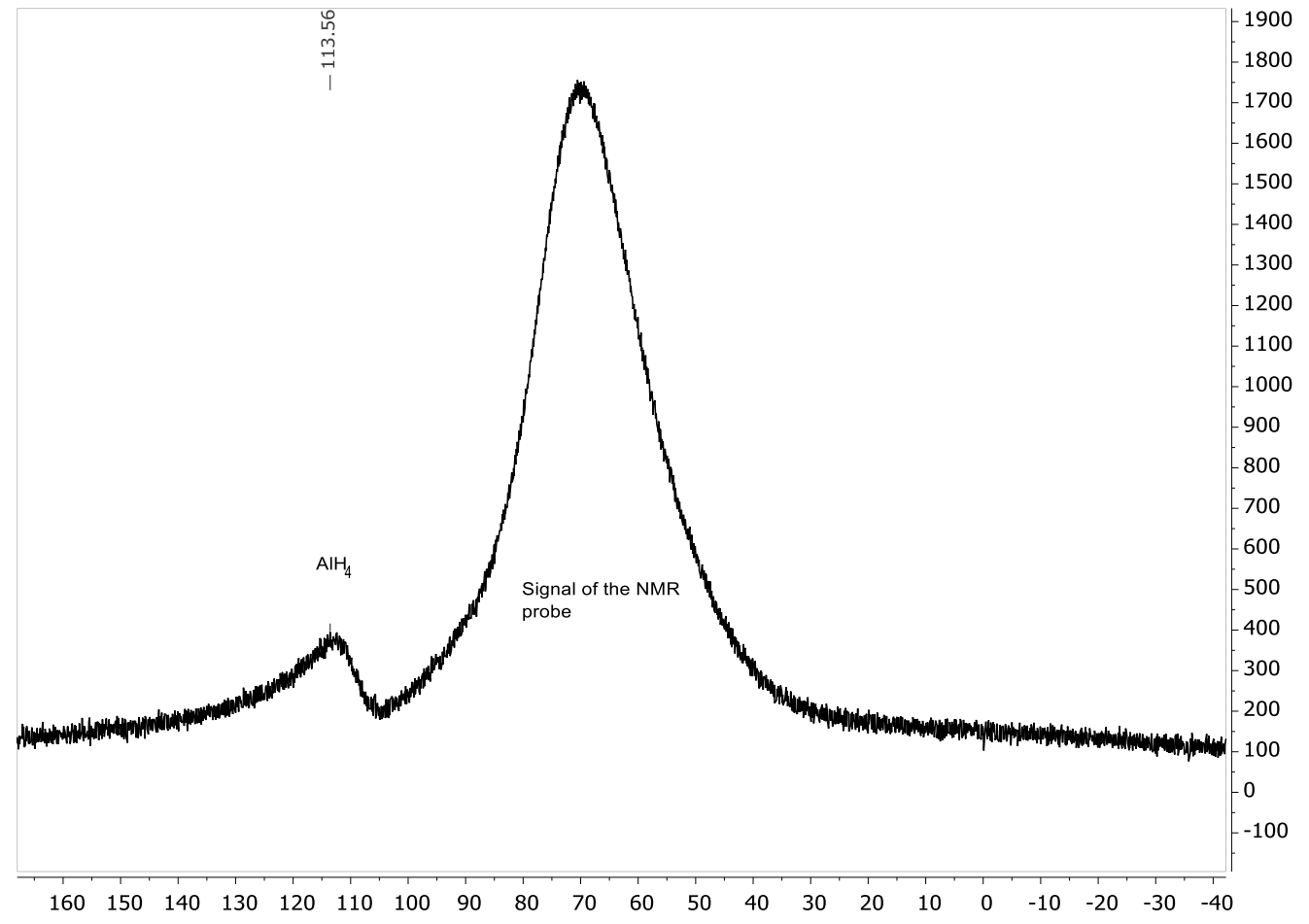

Fig. S2: ${ }^{27} \mathrm{Al}-\mathrm{NMR}$ of the $\mathrm{Mg}\left(\mathrm{AlH}_{4}\right)_{2} \cdot(\mathrm{THF})_{4}$ in THF-d8. 


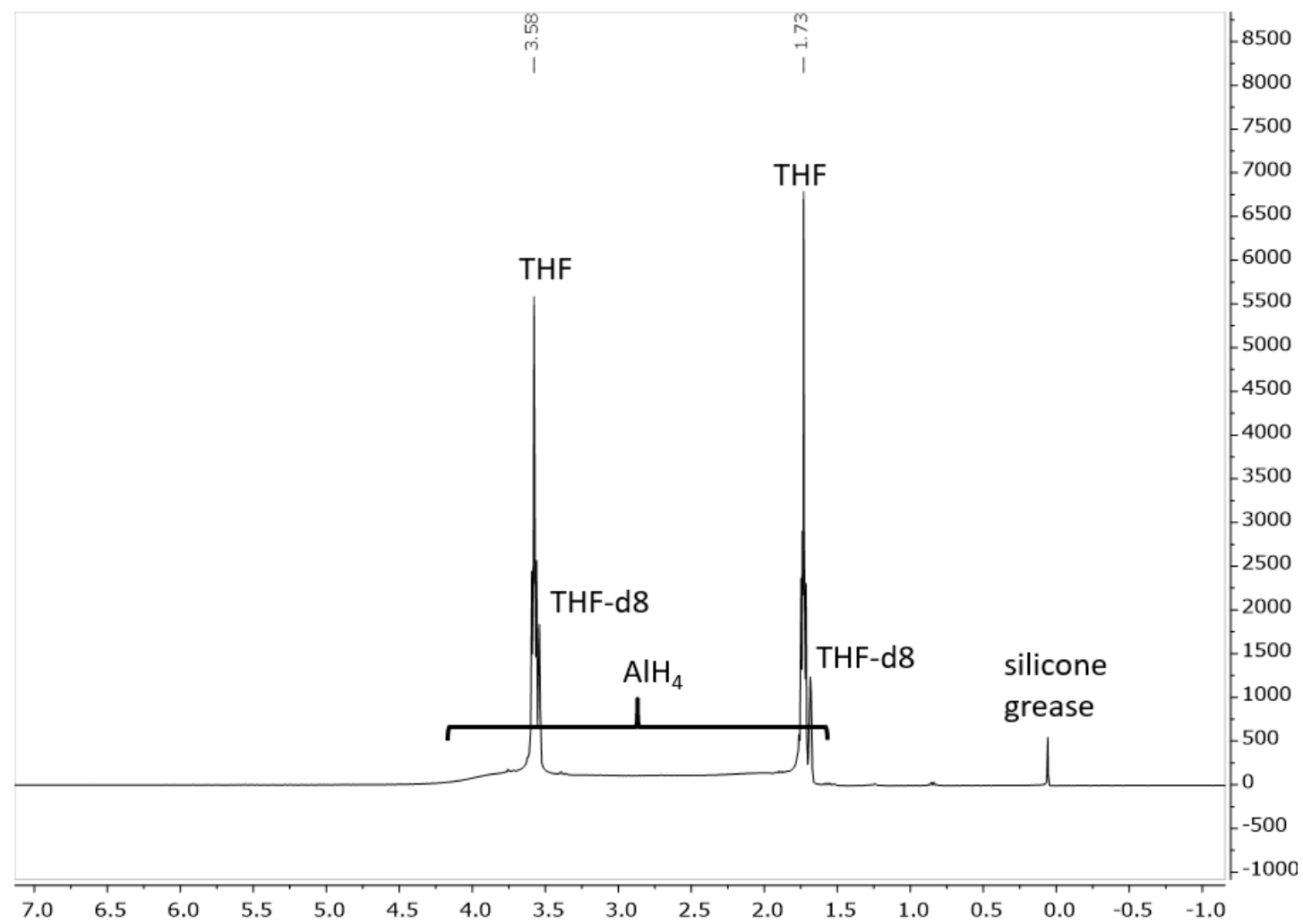

Fig. S3: ${ }^{1} \mathrm{H}-\mathrm{NMR}$ of $\mathrm{Ca}\left(\mathrm{AlH}_{4}\right)_{2} \cdot(\mathrm{THF})_{4}$ in THF-d8. The hydrides are broadened due to coupling with the ${ }^{27} \mathrm{Al}$ nucleus $(1.5-4.25 \mathrm{ppm})$

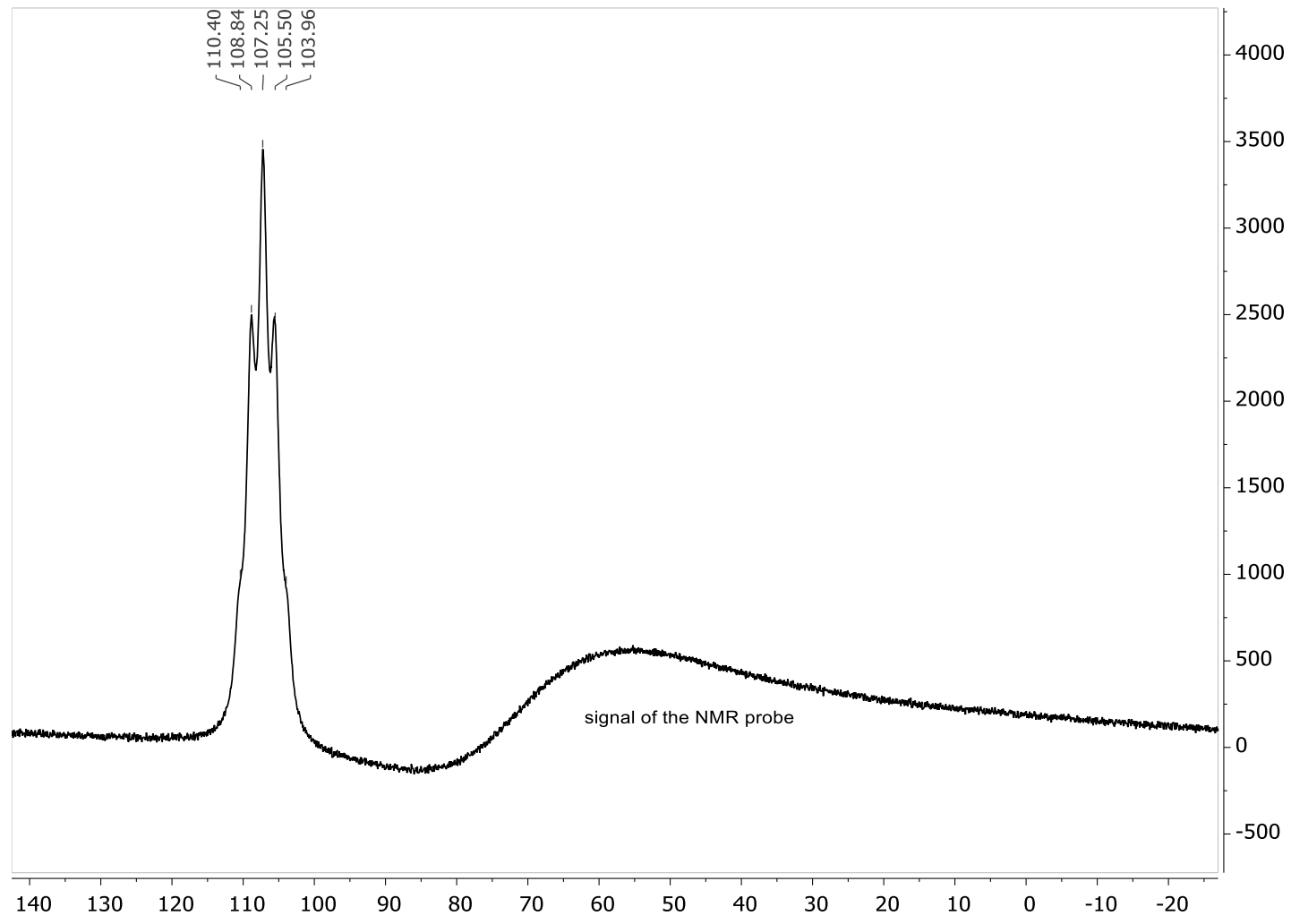

Fig. S4: ${ }^{27} \mathrm{Al}-\mathrm{NMR}$ of the $\left.\mathrm{Ca}(\mathrm{AlH})_{4}\right)_{2} \cdot(\mathrm{THF})_{4}$ in THF-d8. (quint, ${ }^{1} J_{\mathrm{Al}-\mathrm{H}}=182 \mathrm{~Hz}$ ) 


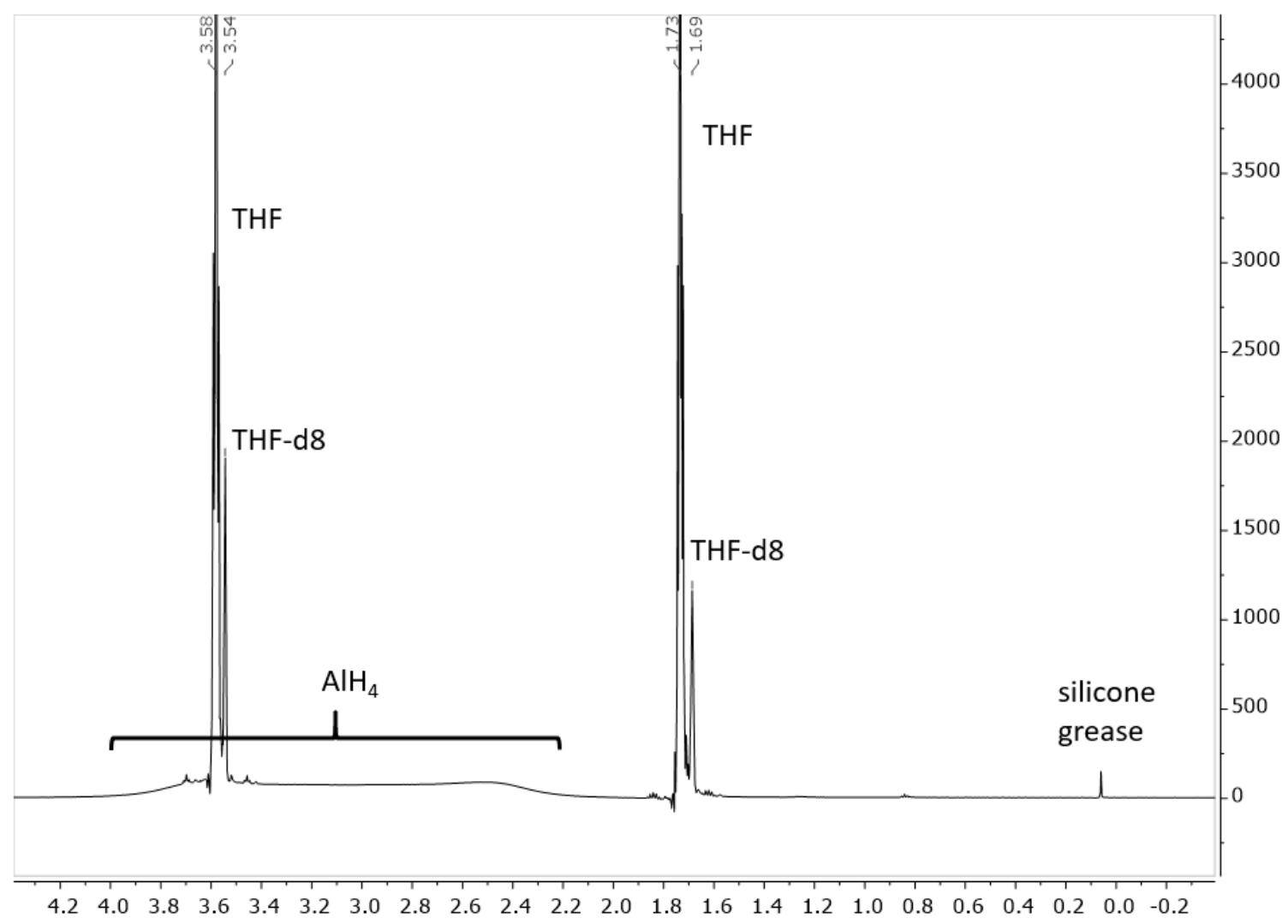

Fig. S5: ${ }^{1} \mathrm{H}-\mathrm{NMR}$ of $\mathrm{Sr}\left(\mathrm{AlH}_{4}\right)_{2} \cdot(\mathrm{THF})_{5}$ in THF-d8

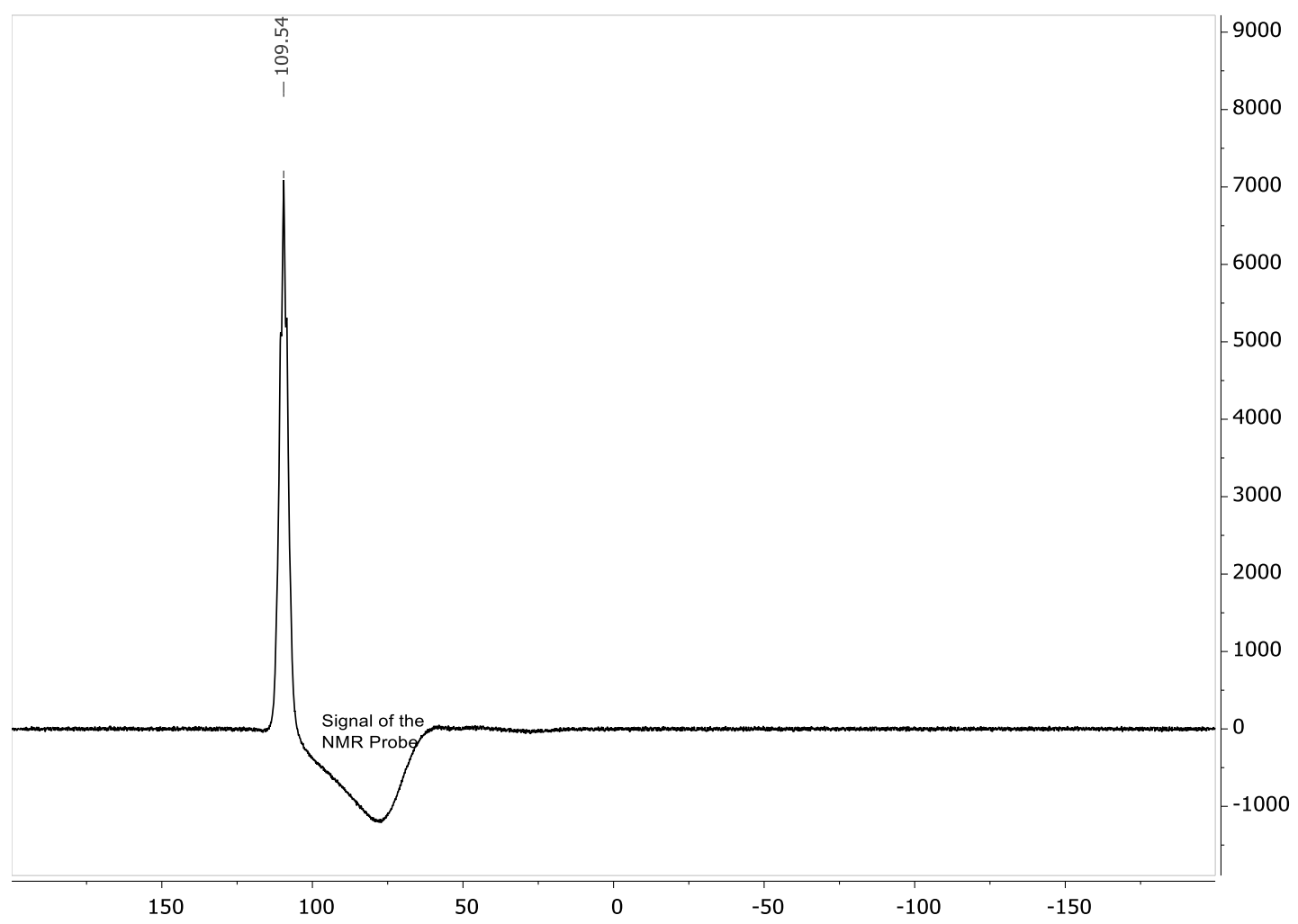

Fig. S6: ${ }^{27} \mathrm{Al}-\mathrm{NMR}$ of $\mathrm{Sr}\left(\mathrm{AlH}_{4}\right)_{2} \cdot(\mathrm{THF})_{5}$ in THF-d8 


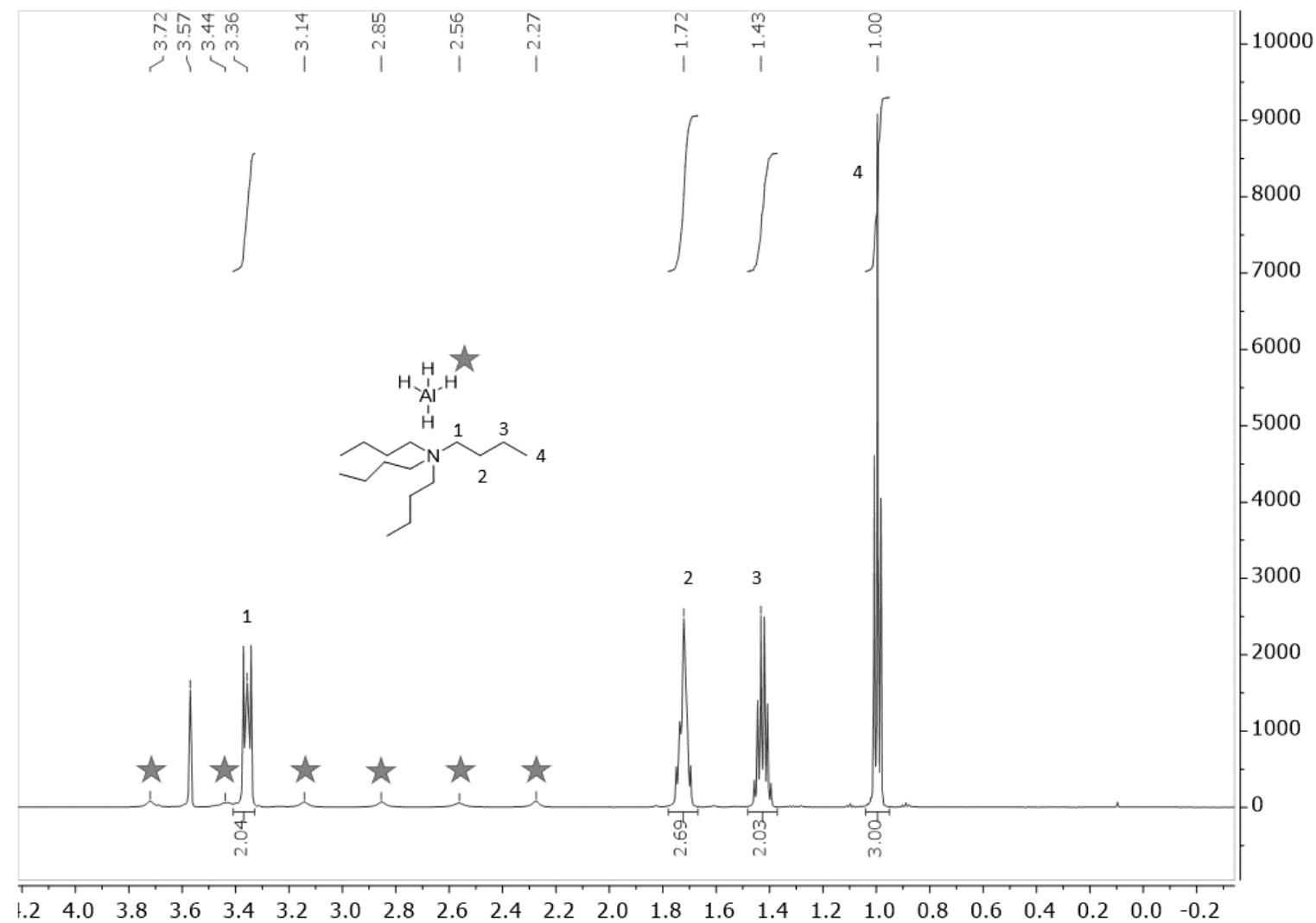

Fig. S7: ${ }^{1} \mathrm{H}-\mathrm{NMR}$ of $\left[n \mathrm{Bu}_{4} \mathrm{~N}^{+}\right]\left[\mathrm{AlH}_{4}{ }^{-}\right]$in THF-d8

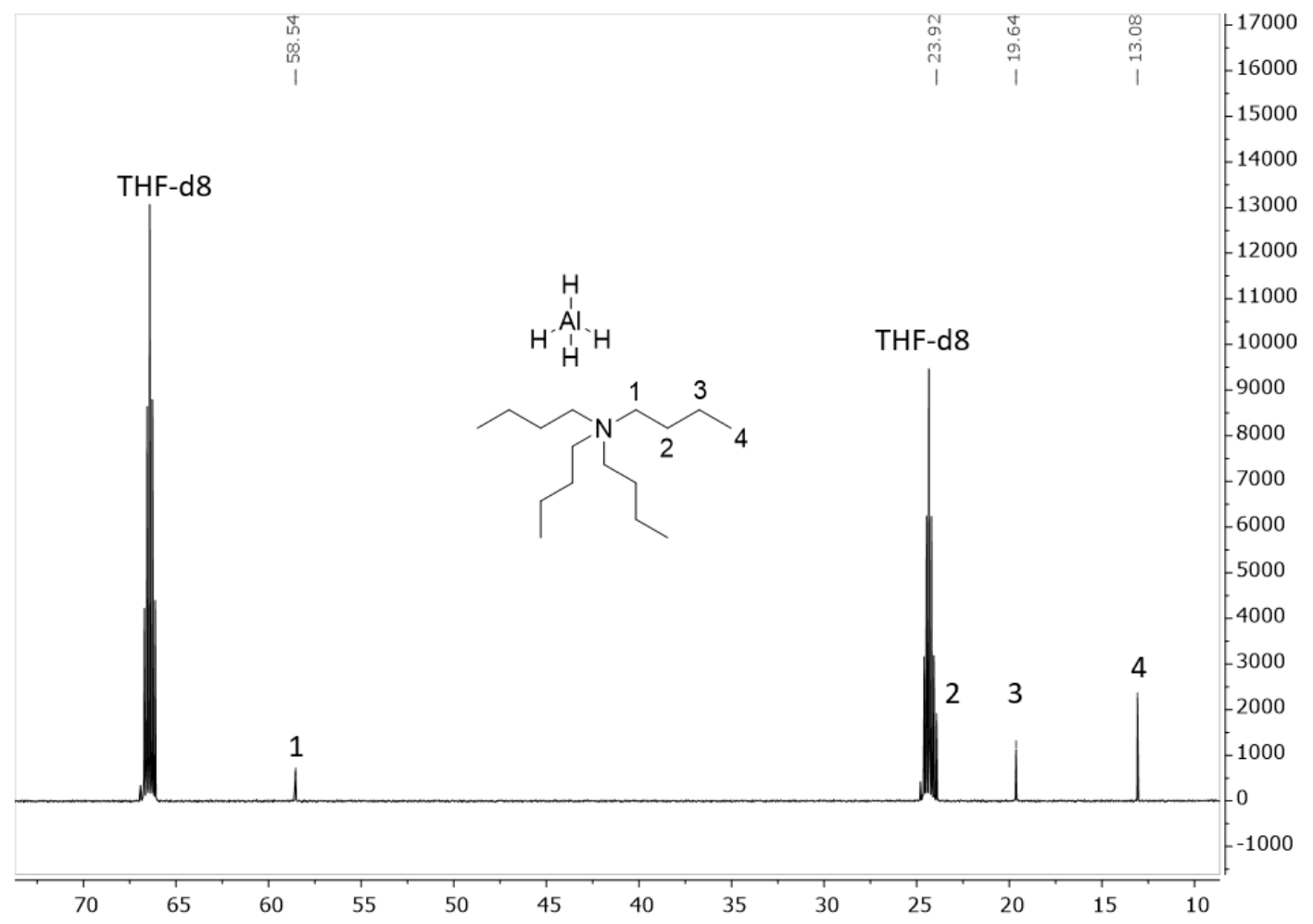

Fig. S8: ${ }^{13} \mathrm{C}-\mathrm{NMR}$ of $\left[n \mathrm{Bu}_{4} \mathrm{~N}^{+}\right]\left[\mathrm{AlH}_{4}{ }^{-}\right]$in THF-d8 


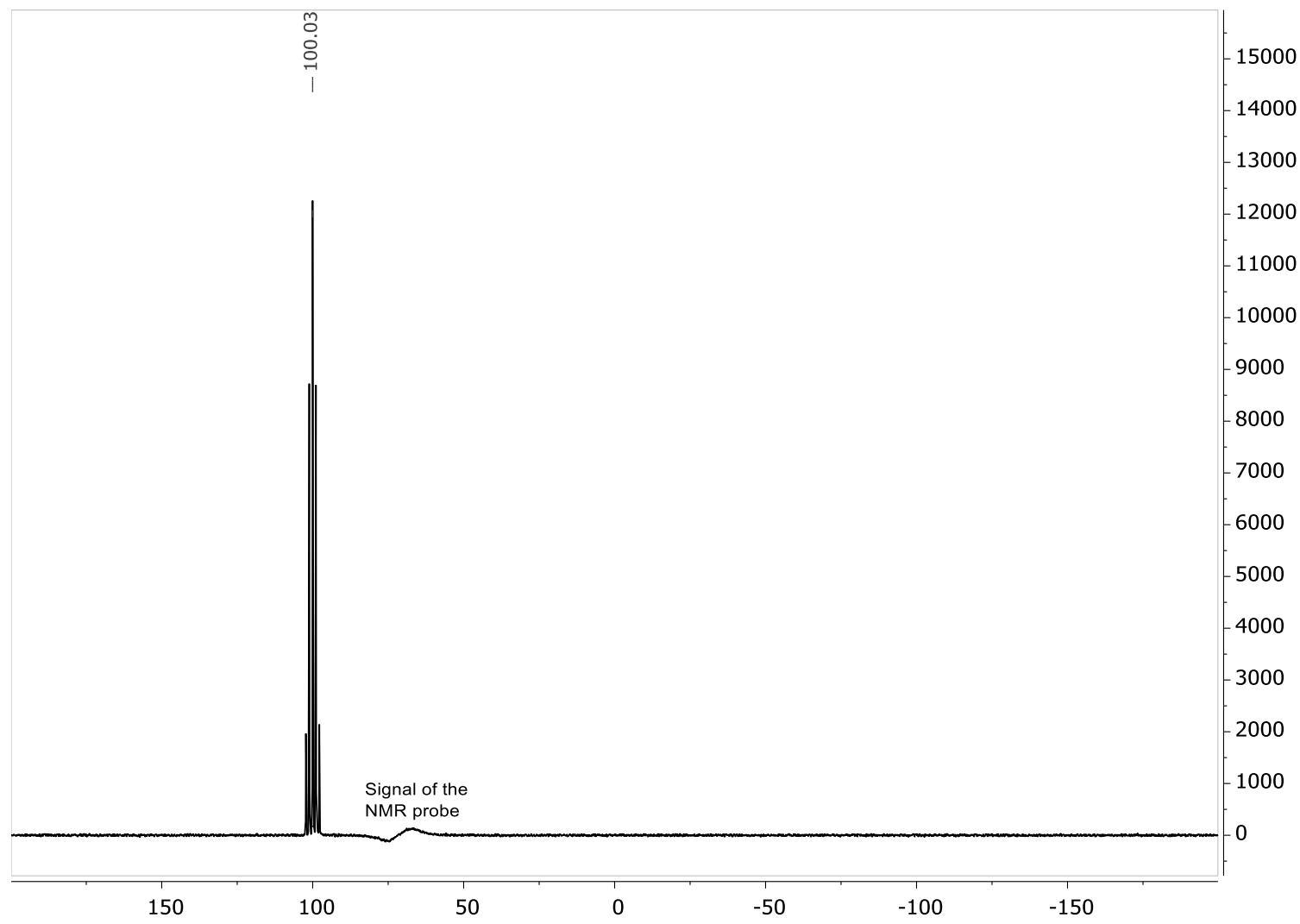

Fig. S9: ${ }^{27} \mathrm{Al}-\mathrm{NMR}$ of $\left[n \mathrm{Bu}_{4} \mathrm{~N}^{+}\right]\left[\mathrm{AlH}_{4}{ }^{-}\right]$in THF-d8

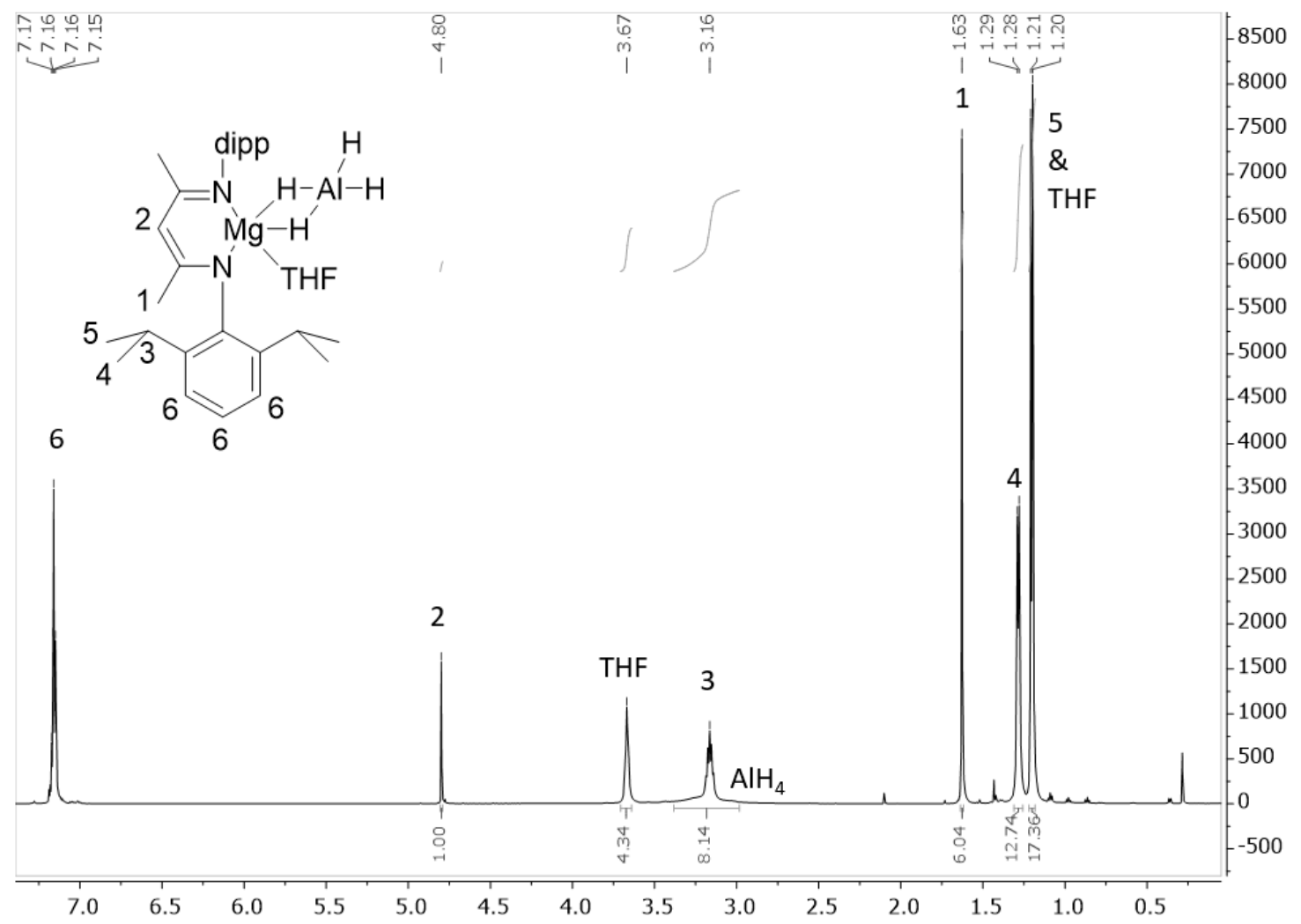

Fig. S10: ${ }^{1} \mathrm{H}-\mathrm{NMR}$ of $\left({ }^{\mathrm{DIPP}} \mathrm{BDI}\right) \mathrm{Mg}\left(\mathrm{AlH}_{4}\right) \cdot \mathrm{THF}$ in $\mathrm{C}_{6} \mathrm{D}_{6}$ 


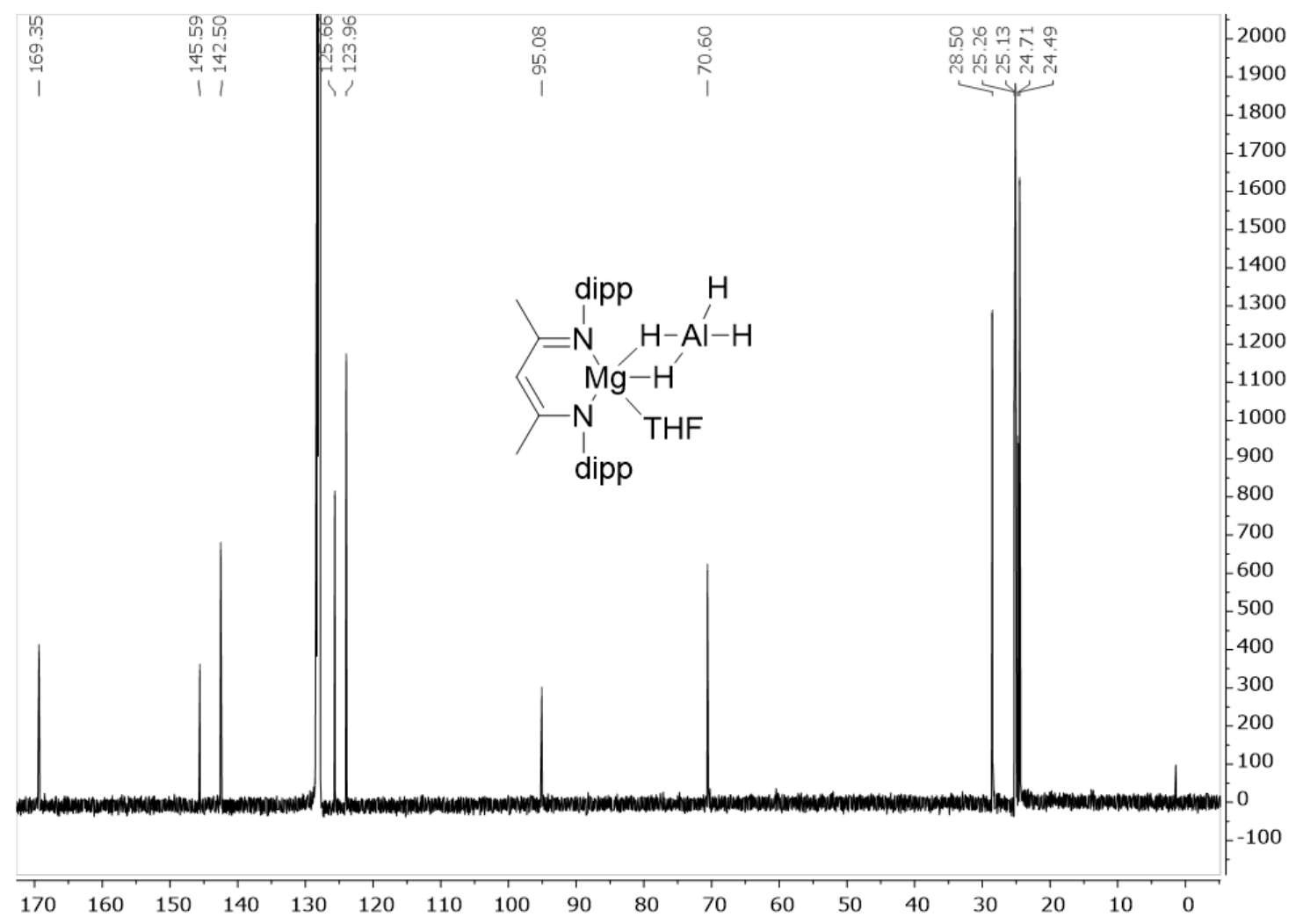

Fig. S11: ${ }^{13} \mathrm{C}-\mathrm{NMR}$ of ( $\left.{ }^{\mathrm{DIPP}} \mathrm{BDI}\right) \mathrm{Mg}\left(\mathrm{AlH}_{4}\right) \cdot \mathrm{THF}$ in $\mathrm{C}_{6} \mathrm{D}_{6}$

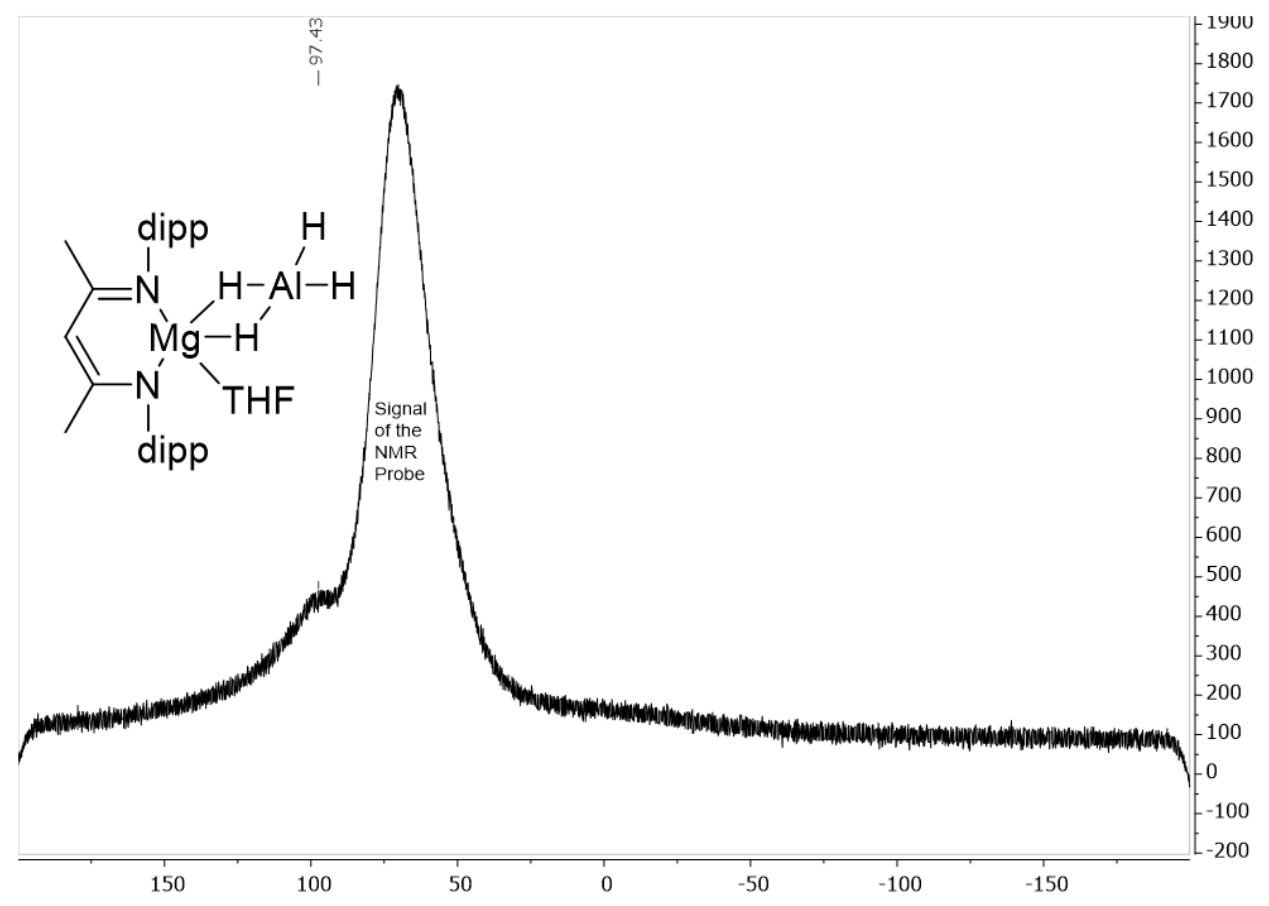

Fig. S12: ${ }^{27} \mathrm{Al}-\mathrm{NMR}$ of $\left({ }^{\mathrm{DIPP}} \mathrm{BDI}\right) \mathrm{Mg}\left(\mathrm{AlH}_{4}\right) \cdot \mathrm{THF}$ in $\mathrm{C}_{6} \mathrm{D}_{6}$ 


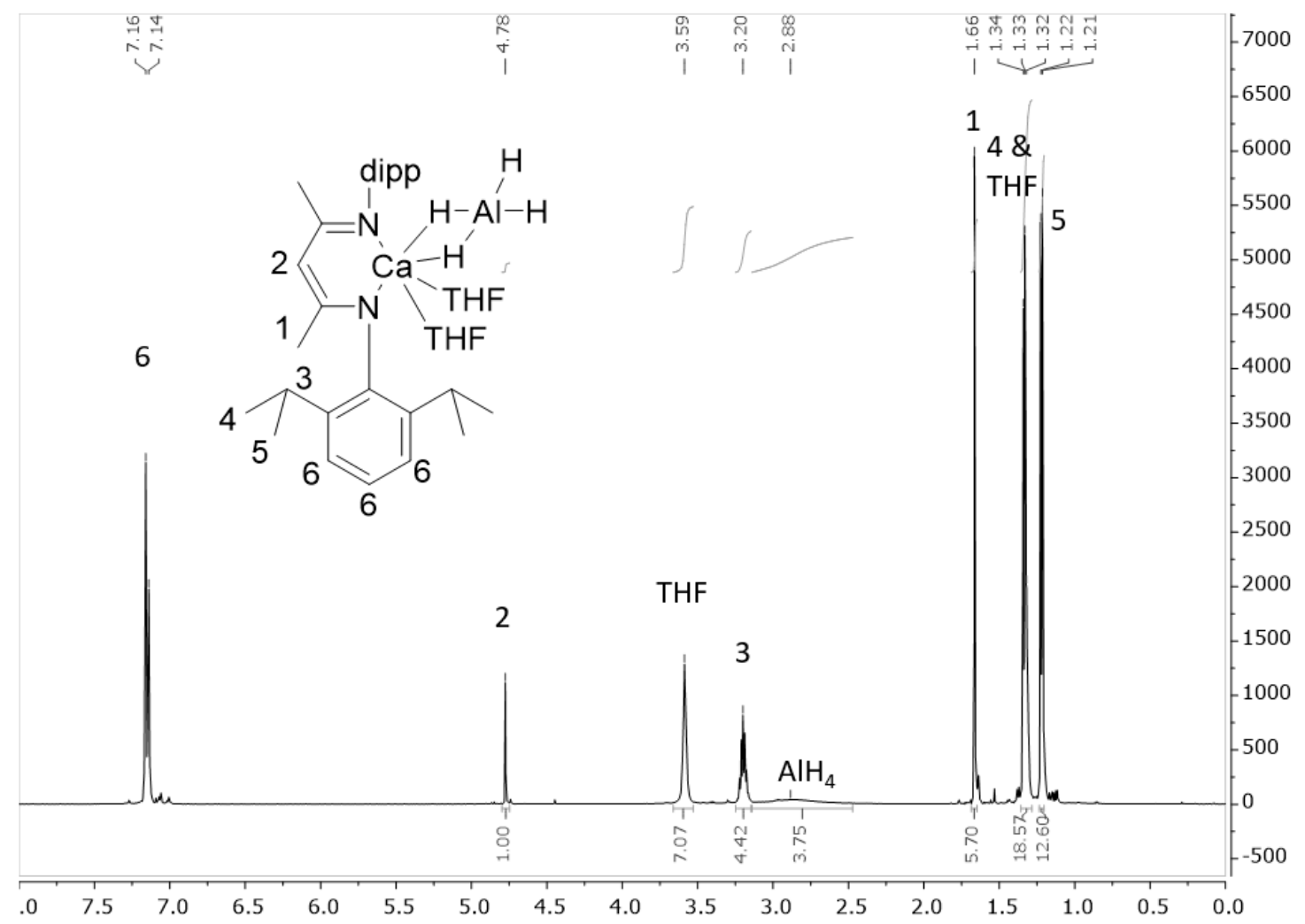

Fig. S13: ${ }^{1} \mathrm{H}-\mathrm{NMR}$ of $\left({ }^{\mathrm{DIPP}} \mathrm{BDI}\right) \mathrm{Ca}\left(\mathrm{AlH}_{4}\right) \cdot \mathrm{THF}_{2}$ in $\mathrm{C}_{6} \mathrm{D}_{6}$

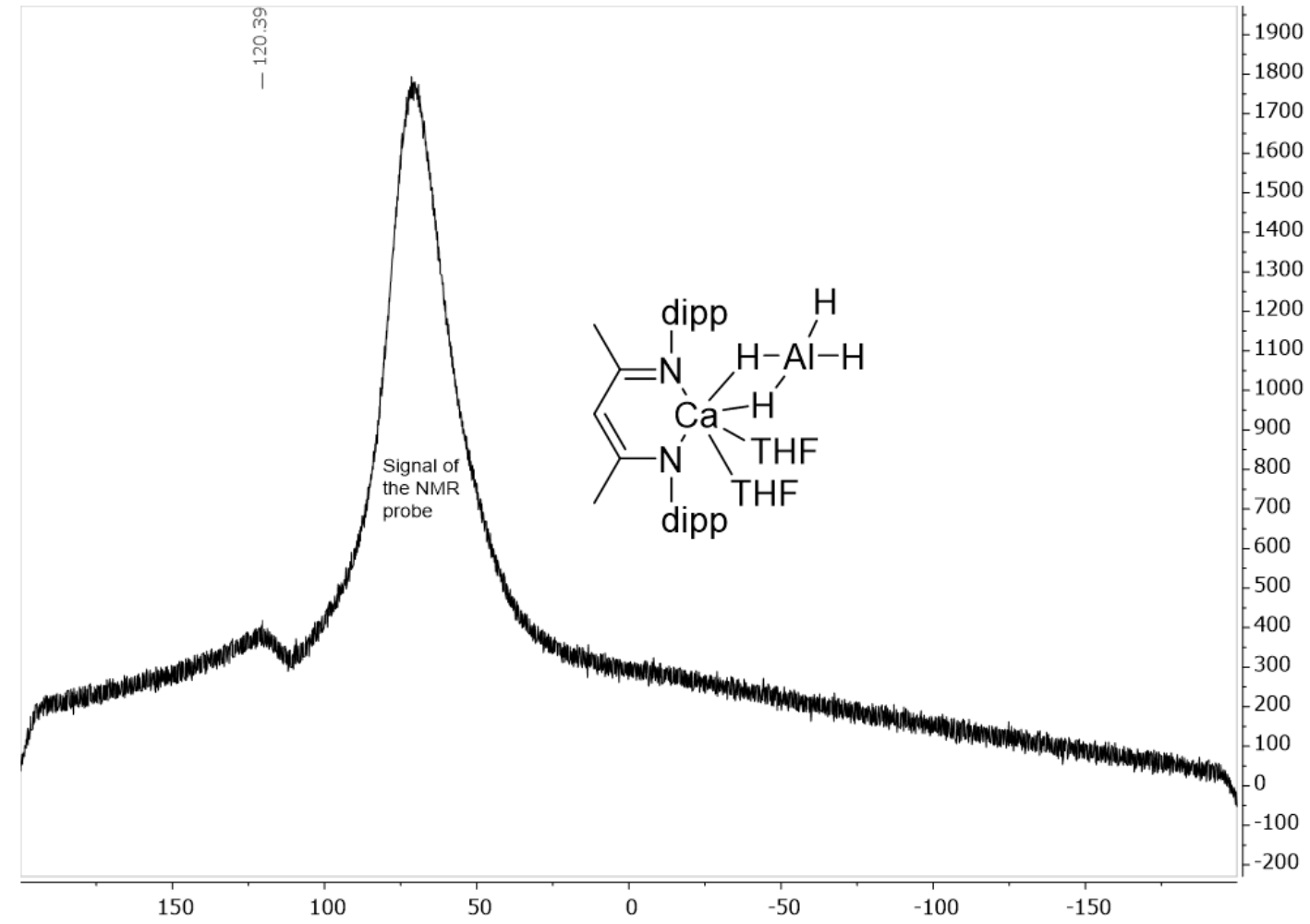

Fig. S14: ${ }^{27} \mathrm{Al}-\mathrm{NMR}$ of $\left({ }^{\mathrm{DIPP}} \mathrm{BDI}\right) \mathrm{Ca}\left(\mathrm{AlH}_{4}\right) \cdot \mathrm{THF}_{2}$ in $\mathrm{C}_{6} \mathrm{D}_{6}$ 


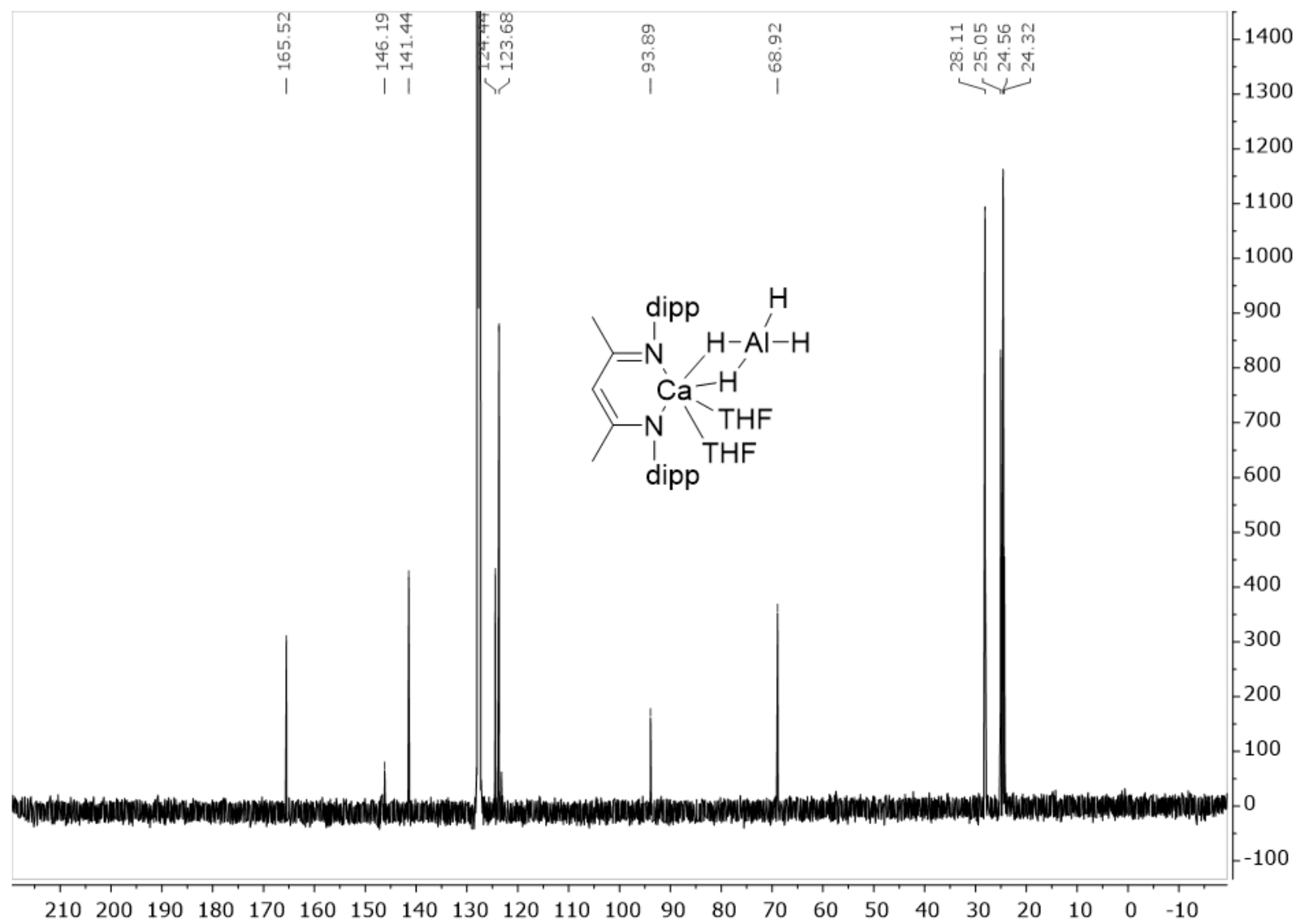

Fig. S15: ${ }^{13} \mathrm{C}-\mathrm{NMR}$ of ( $\left.{ }^{\mathrm{DIPP}} \mathrm{BDI}\right) \mathrm{Ca}\left(\mathrm{AlH}_{4}\right) \cdot \mathrm{THF}_{2}$ in $\mathrm{C}_{6} \mathrm{D}_{6}$

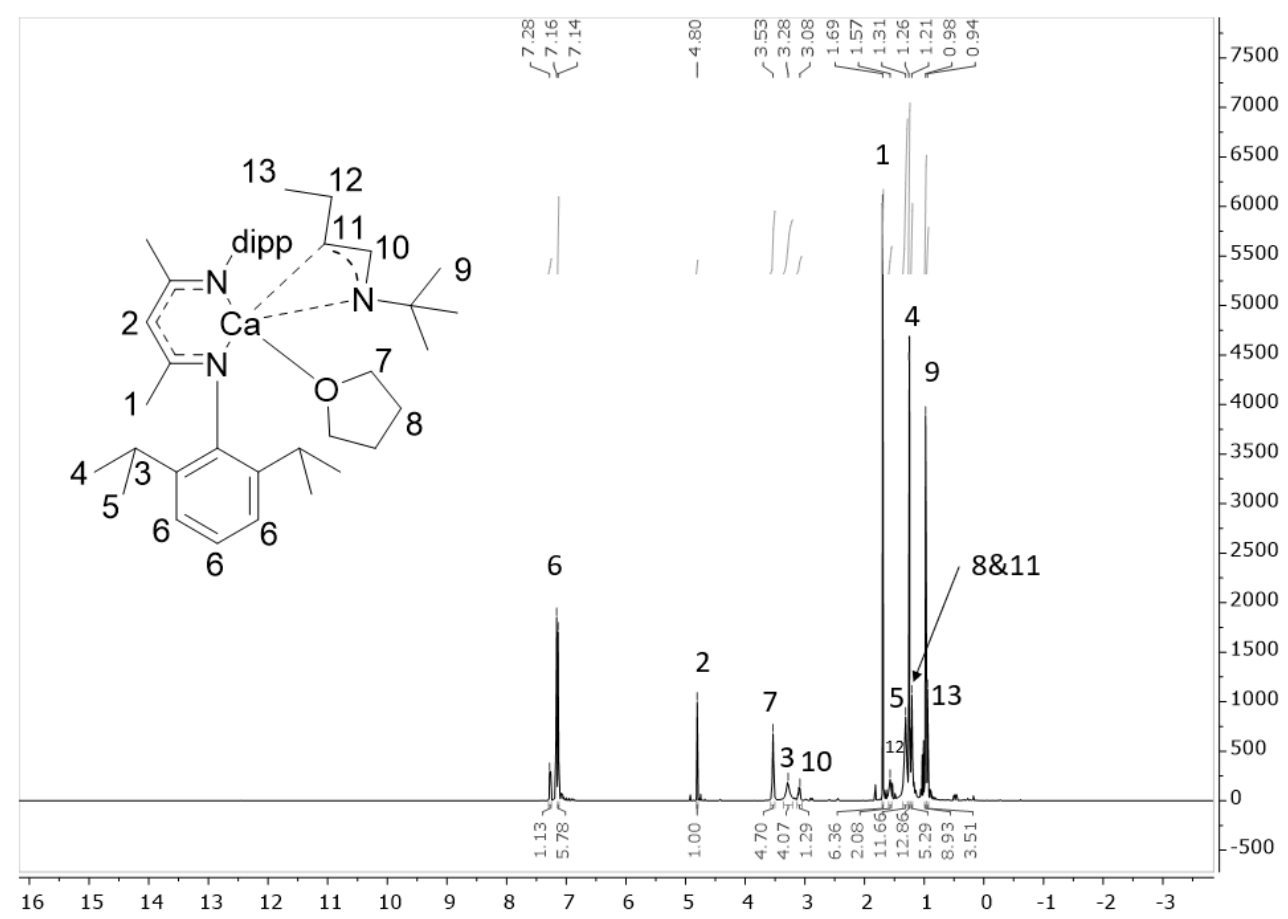

Fig. S16: ${ }^{1} \mathrm{H}-\mathrm{NMR}$ of $\left({ }^{\mathrm{DIPP}} \mathrm{BDI}\right) \mathrm{Ca}[\mathrm{N}(\mathrm{tBu})(\mathrm{HC}=\mathrm{C}(\mathrm{H}) \mathrm{Et})] \cdot \mathrm{THF}$ in $\mathrm{C}_{6} \mathrm{D}_{6}$. 


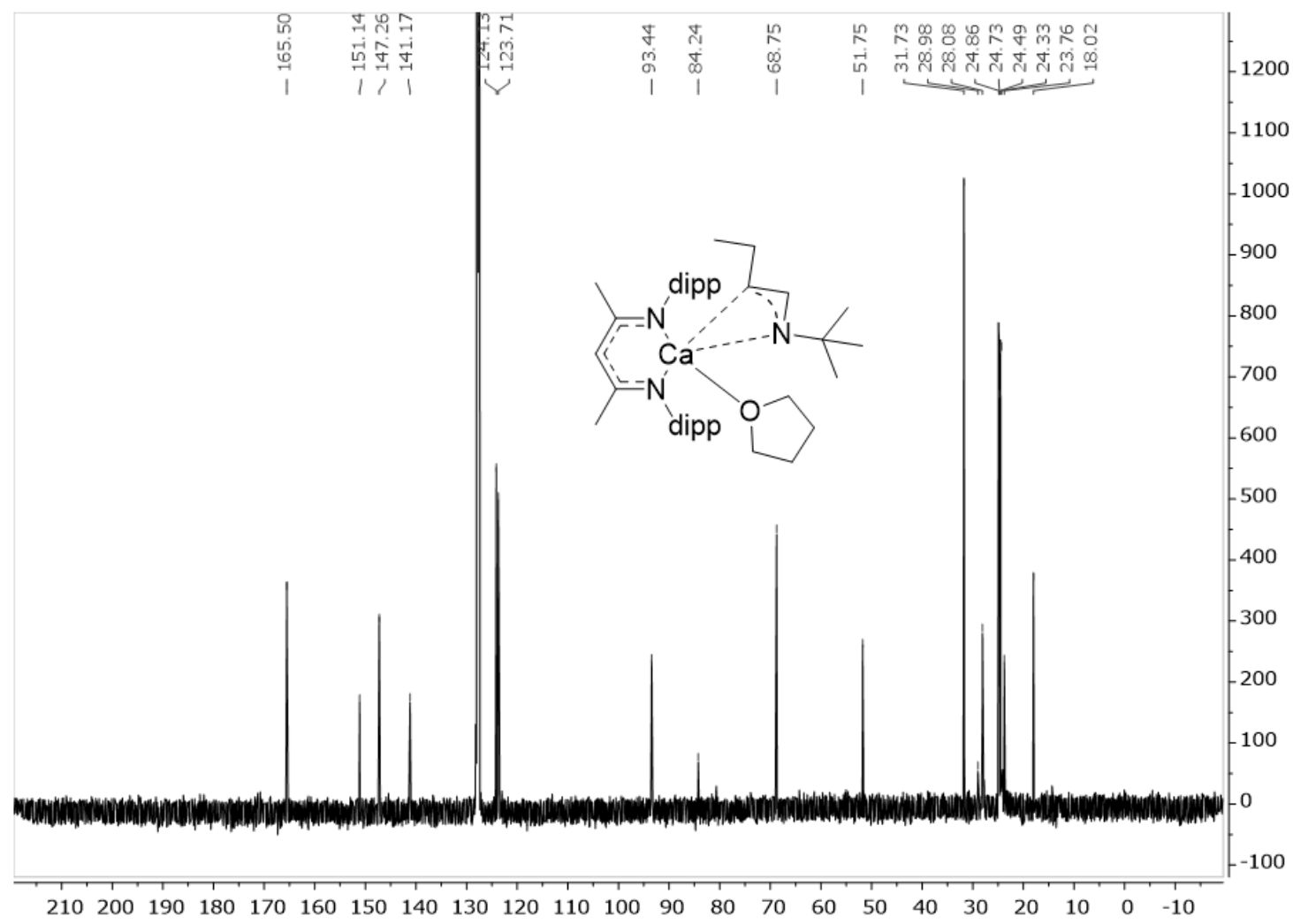

Fig. S17: ${ }^{13} \mathrm{C}-\mathrm{NMR}$ of $\left({ }^{\mathrm{DIPP}} \mathrm{BDI}\right) \mathrm{Ca}[\mathrm{N}(t \mathrm{Bu})(\mathrm{HC}=\mathrm{C}(\mathrm{H}) \mathrm{Et})] \cdot \mathrm{THF}$ in $\mathrm{C}_{6} \mathrm{D}_{6}$. 


\section{Catalytic Imine Hydrogenation}

Catalytic experiments were performed in a stainless steel $15 \mathrm{ml}$ autoclave. The autoclave was dried in an oven $\left(75^{\circ} \mathrm{C}\right)$ prior to transfer to a glove box charged with nitrogen. All reactants were placed in the autoclave under inert atmosphere. Catalytic reactions were carried out using $2.81 \mathrm{mmol}$ of substrate and a catalyst loading of $0.281 \mathrm{mmol}(10 \mathrm{~mol} \%), 0.141 \mathrm{mmol}(5 \mathrm{~mol} \%)$ or $0.0702 \mathrm{mmol}$ ( $2.5 \mathrm{~mol} \%)$. Reactors were charged with $\mathrm{H}_{2}$ of quality $\mathrm{N} 5$ to the desired pressure and heated in a heating block to the desired temperature. Conversions were determined by integration of characteristic ${ }^{1} \mathrm{H}$ NMR signals. ${ }^{1} \mathrm{H}$ NMR data of the products were compared with literature values. For the solid substrate $\mathrm{Ph}(\mathrm{H}) \mathrm{C}=\mathrm{NPh}, 1 \mathrm{~mL}$ of THF was added and, due to overlap of substrate-product ${ }^{1} \mathrm{H}$ NMR signals, conversion was estimated by GC-MS analysis.

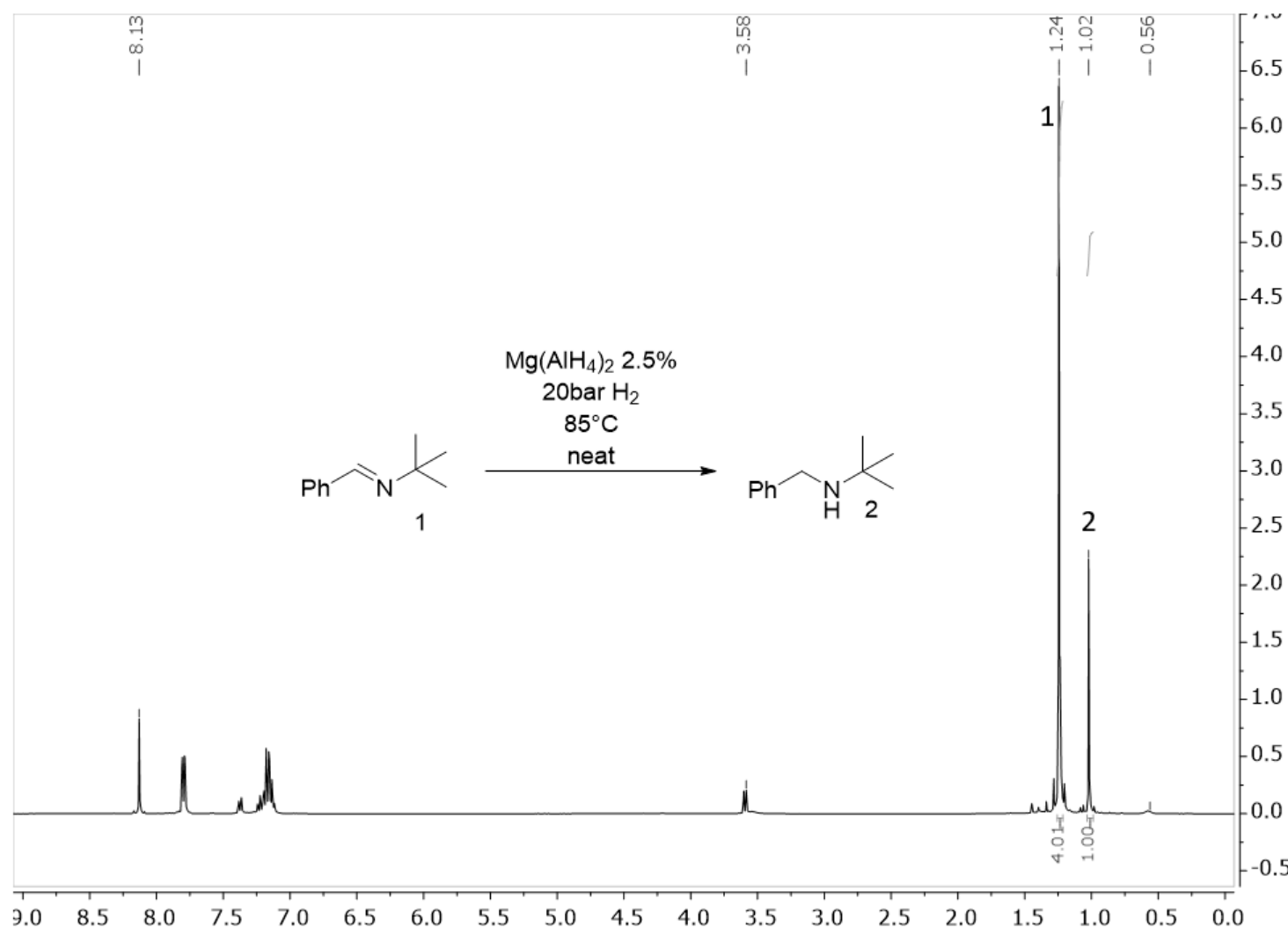

Fig. S18: ${ }^{1} \mathrm{H}$ NMR spectrum for the reaction of $\mathrm{Ph}(\mathrm{CH})=\mathrm{N} t \mathrm{Bu}$ with $\mathrm{Mg}\left(\mathrm{AlH}_{4}\right)_{2} \cdot(\mathrm{THF})_{4}(2.5 \%)$ at 20 bar $\mathrm{H}_{2}$ at $85^{\circ} \mathrm{C}$ for $2.5 \mathrm{~h}$ in $\mathrm{C}_{6} \mathrm{D}_{6}$. 


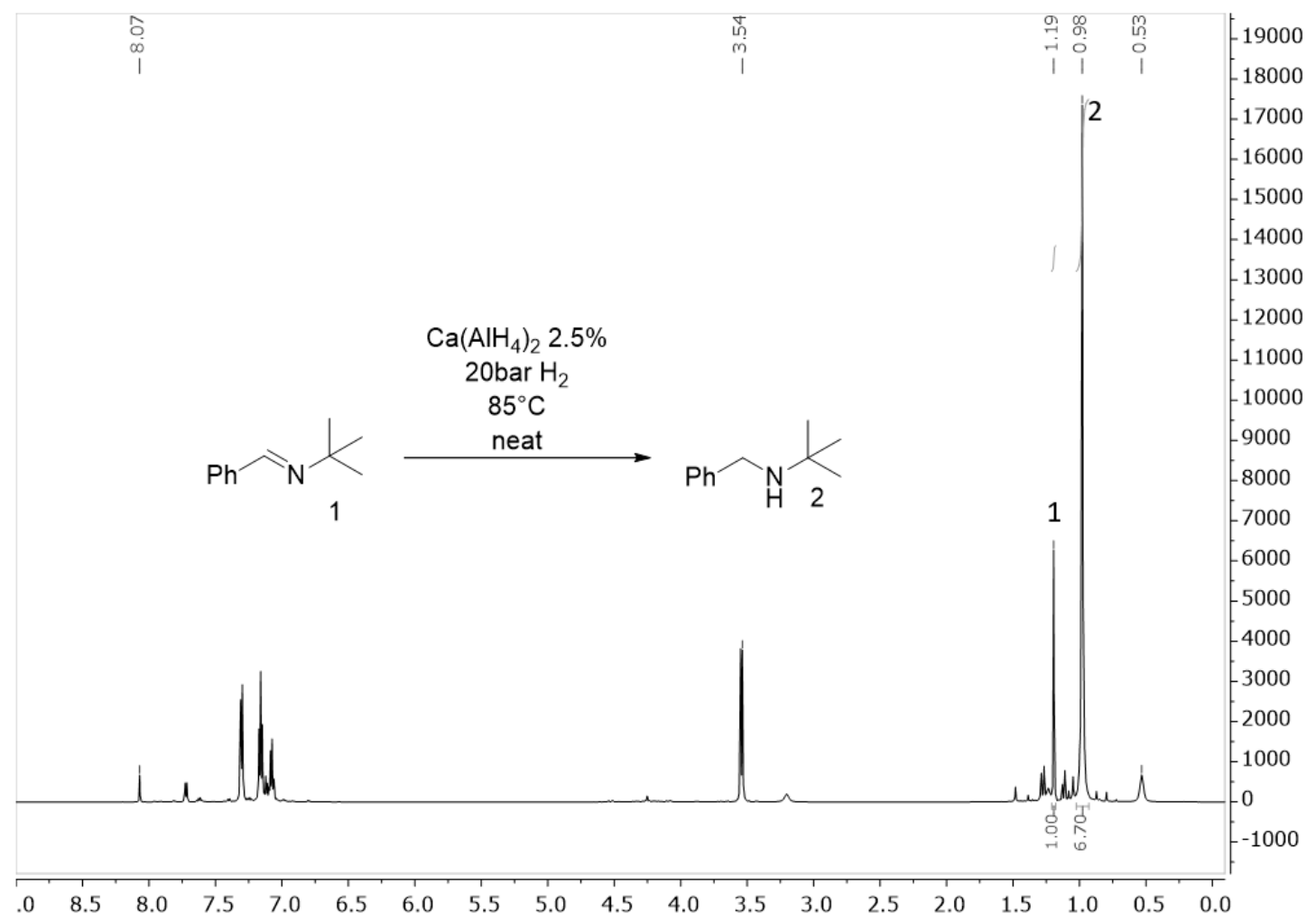

Fig. S19: ${ }^{1} \mathrm{H}$ NMR spectrum for the reaction of $\mathrm{Ph}(\mathrm{CH})=\mathrm{N} t \mathrm{Bu}$ with $\mathrm{Ca}\left(\mathrm{AlH}_{4}\right)_{2} \cdot(\mathrm{THF})_{4}(2.5 \%)$ at 20 bar $\mathrm{H}_{2}$ at $85^{\circ} \mathrm{C}$ for $2.5 \mathrm{~h}$ in $\mathrm{C}_{6} \mathrm{D}_{6}$.

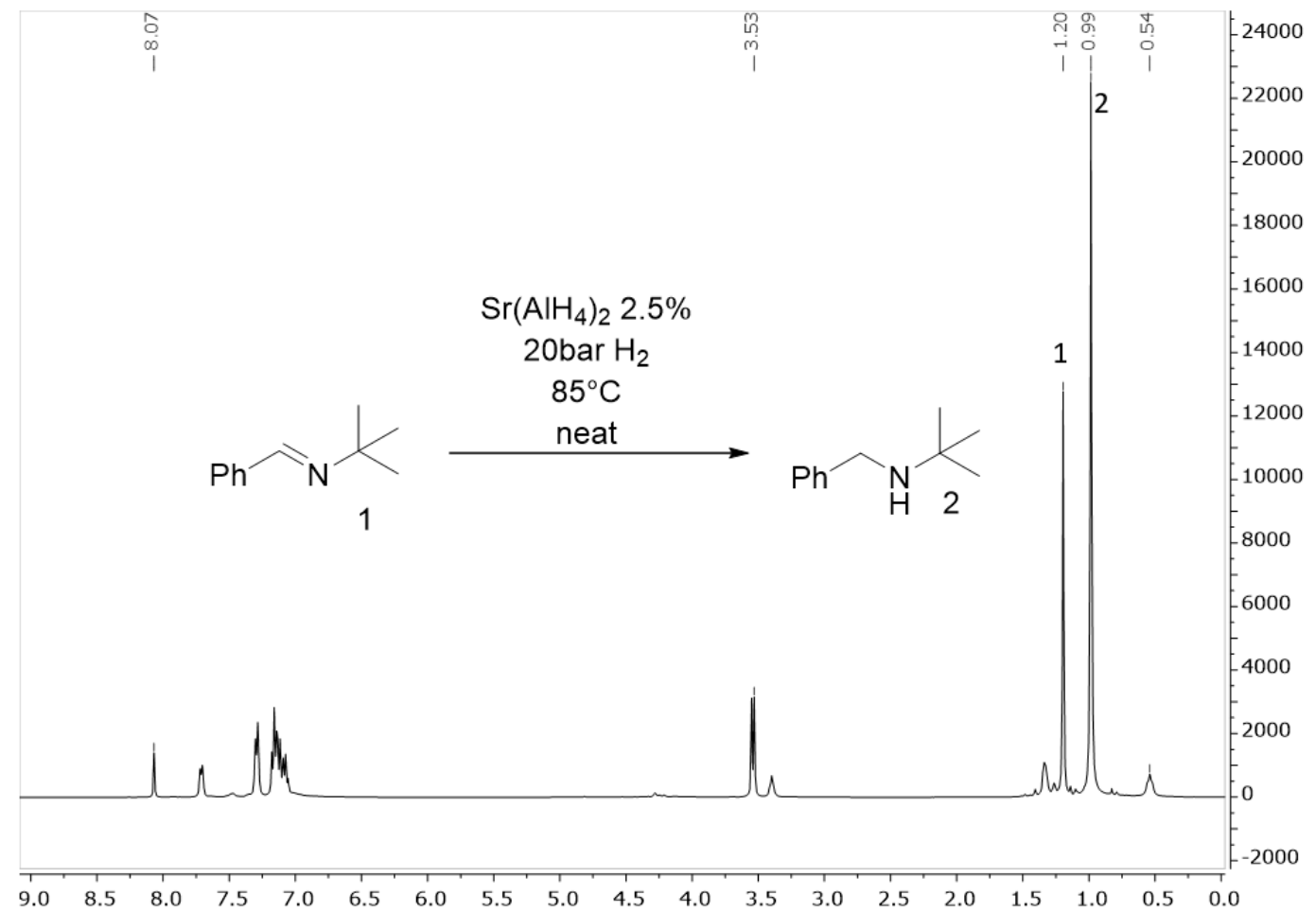

Fig. S20: ${ }^{1} \mathrm{H}$ NMR spectrum for the reaction of $\mathrm{Ph}(\mathrm{CH})=\mathrm{N} t \mathrm{Bu}$ with $\mathrm{Sr}(\mathrm{AlH})_{4} \cdot(\mathrm{THF})_{5}(2.5 \%)$ at 20 bar $\mathrm{H}_{2}$ at $85^{\circ} \mathrm{C}$ for $1 \mathrm{~h}$ in $\mathrm{C}_{6} \mathrm{D}_{6}$. 


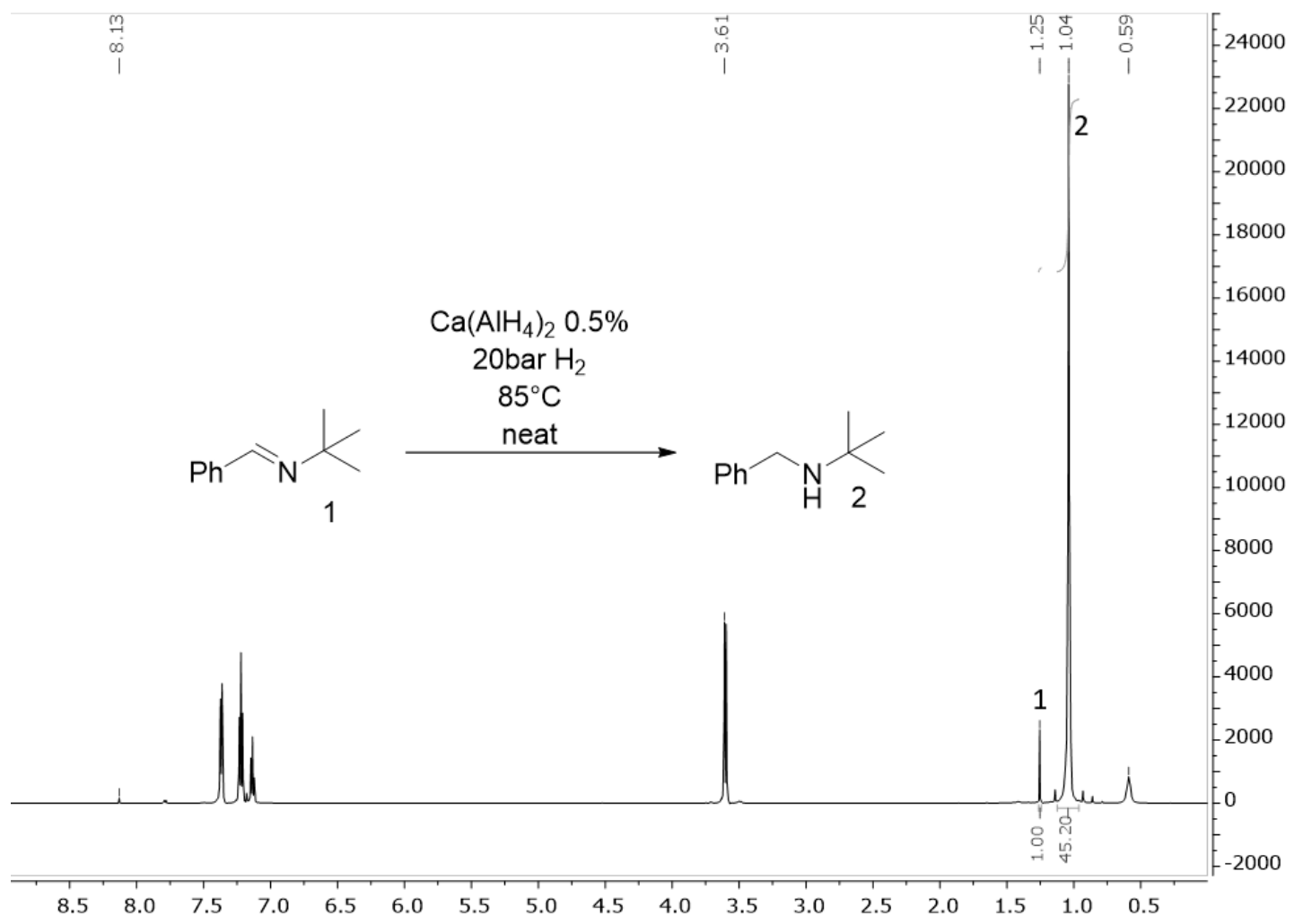

Fig S21: ${ }^{1} \mathrm{H}$ NMR spectrum for the reaction of $\mathrm{Ph}(\mathrm{CH})=\mathrm{NtBu}$ with $\mathrm{Ca}\left(\mathrm{AlH}_{4}\right)_{2} \cdot(\mathrm{THF})_{4}(0.5 \%)$ at 20 bar $\mathrm{H}_{2}$ at $85^{\circ} \mathrm{C}$ for $24 \mathrm{~h}$ in $\mathrm{C}_{6} \mathrm{D}_{6}$.

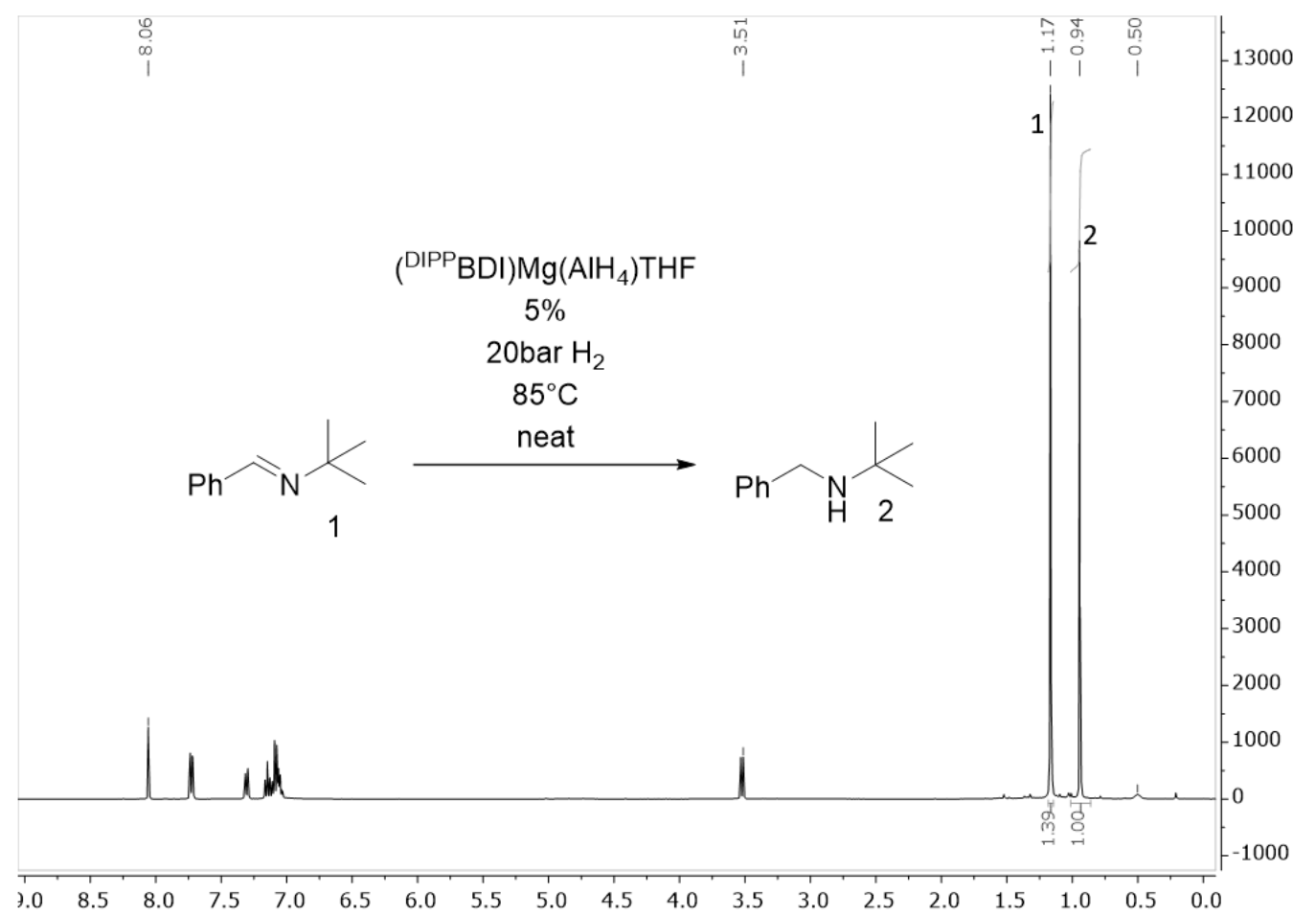

Fig. S22: ${ }^{1} \mathrm{H}$ NMR spectrum for the reaction of $\mathrm{PhC}(\mathrm{H})=\mathrm{NtBu}$ with $\left({ }^{\mathrm{DIPP}} \mathrm{BDI}\right) \mathrm{Mg}\left(\mathrm{AlH} \mathrm{H}_{4}\right) \cdot \mathrm{THF}(5 \%)$ at 20 bar $\mathrm{H}_{2}$ at $85^{\circ} \mathrm{C}$ for $24 \mathrm{~h}$ in $\mathrm{C}_{6} \mathrm{D}_{6}$. 


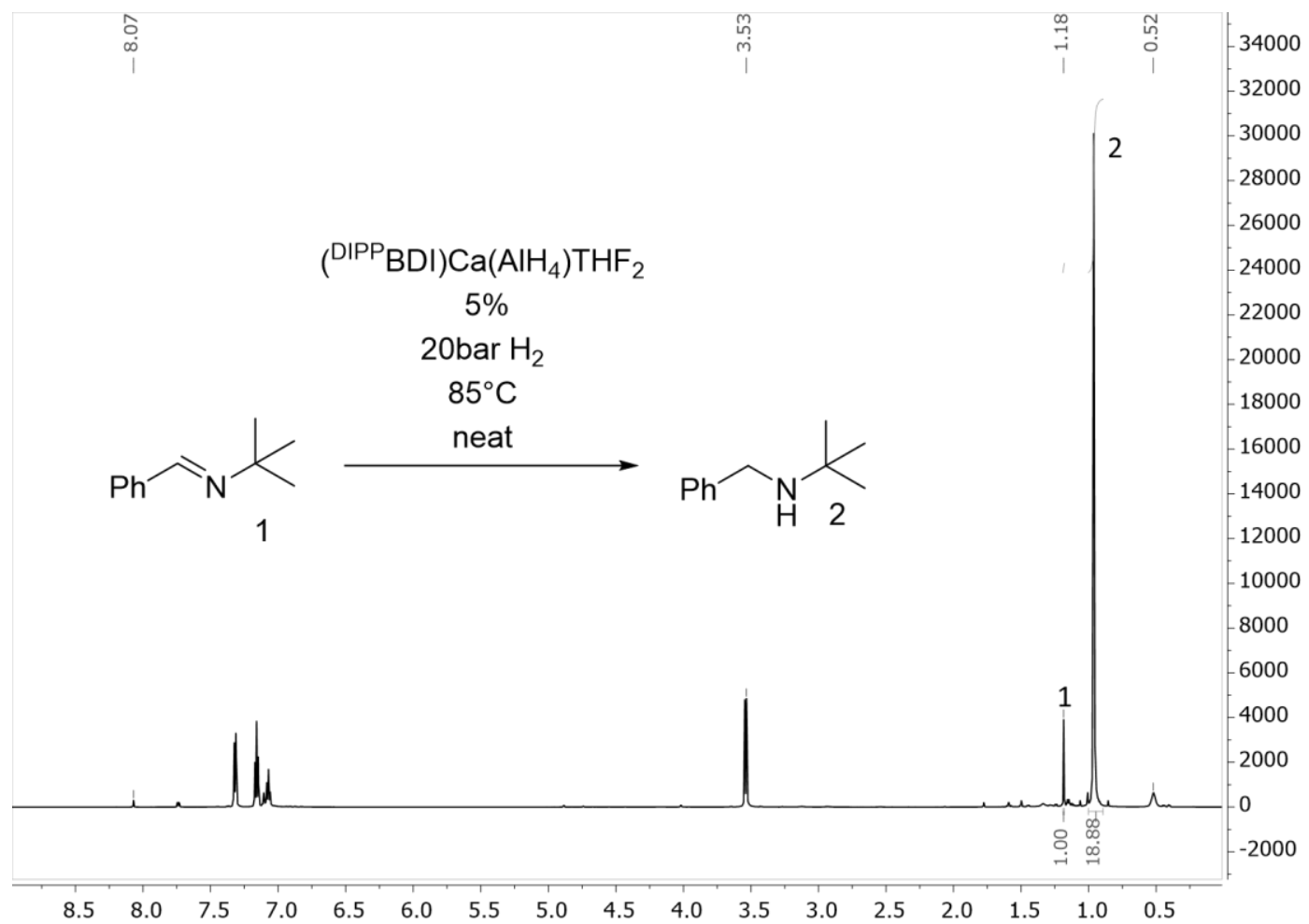

Fig. S23: ${ }^{1} \mathrm{H}$ NMR spectrum for the reaction of $\mathrm{PhC}(\mathrm{H})=\mathrm{NtBu}$ with $\left({ }^{\mathrm{DIPP}} \mathrm{BDI}\right) \mathrm{Ca}\left(\mathrm{AlH}_{4}\right) \cdot \mathrm{THF}_{2}(5 \%)$ at 20 bar $\mathrm{H}_{2}$ at $85^{\circ} \mathrm{C}$ for $24 \mathrm{~h}$ in $\mathrm{C}_{6} \mathrm{D}_{6}$.

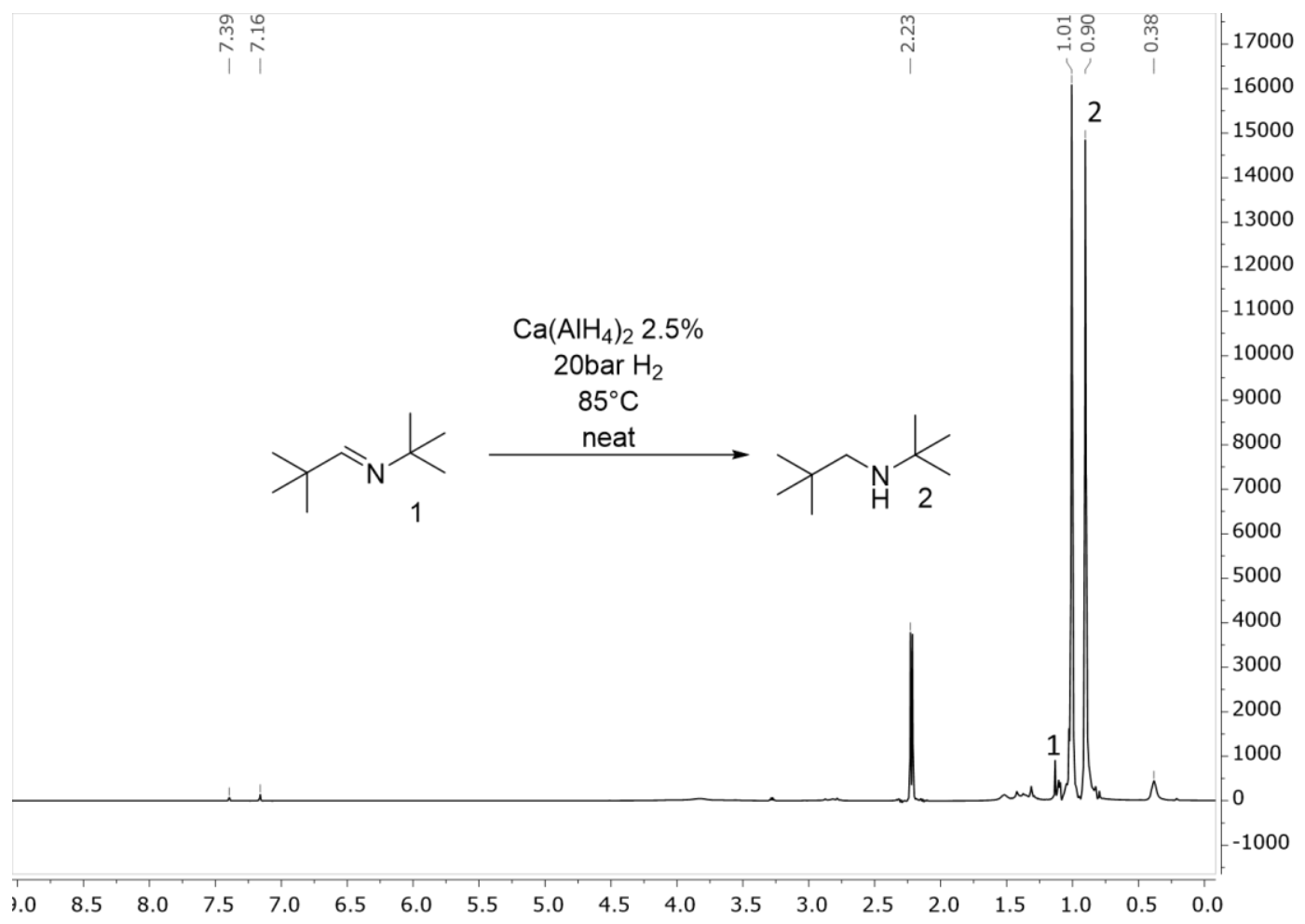

Fig. S24: ${ }^{1} \mathrm{H}$ NMR spectrum for the reaction of $t \mathrm{Bu}(\mathrm{CH})=\mathrm{N} t \mathrm{Bu}$ with $\mathrm{Ca}\left(\mathrm{AlH}_{4}\right)_{2} \cdot(\mathrm{THF})_{4}(2.5 \%)$ at 20 bar $\mathrm{H}_{2}$ at $85^{\circ} \mathrm{C}$ for $2.5 \mathrm{~h}$ in $\mathrm{C}_{6} \mathrm{D}_{6}$. 


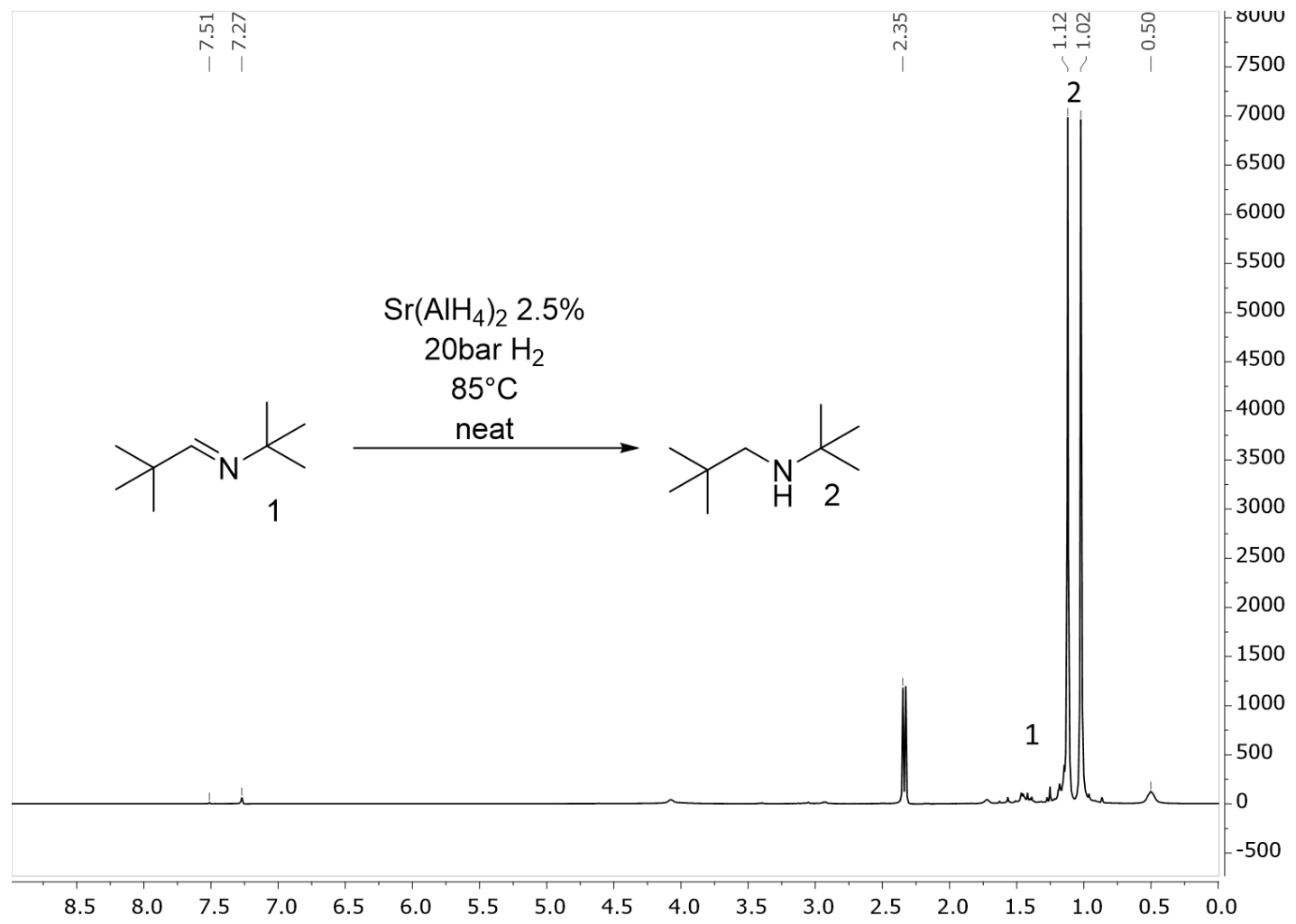

Fig. S25: ${ }^{1} \mathrm{H} N M R$ spectrum for the reaction of $t \mathrm{Bu}(\mathrm{CH})=\mathrm{N} t \mathrm{Bu}$ with $\mathrm{Sr}\left(\mathrm{AlH} \mathrm{H}_{4}\right)_{2} \cdot(\mathrm{THF})_{5}(2.5 \%)$ at 20 bar $\mathrm{H}_{2}$ at $85^{\circ} \mathrm{C}$ for $24 \mathrm{~h}$ in $\mathrm{C}_{6} \mathrm{D}_{6}$.

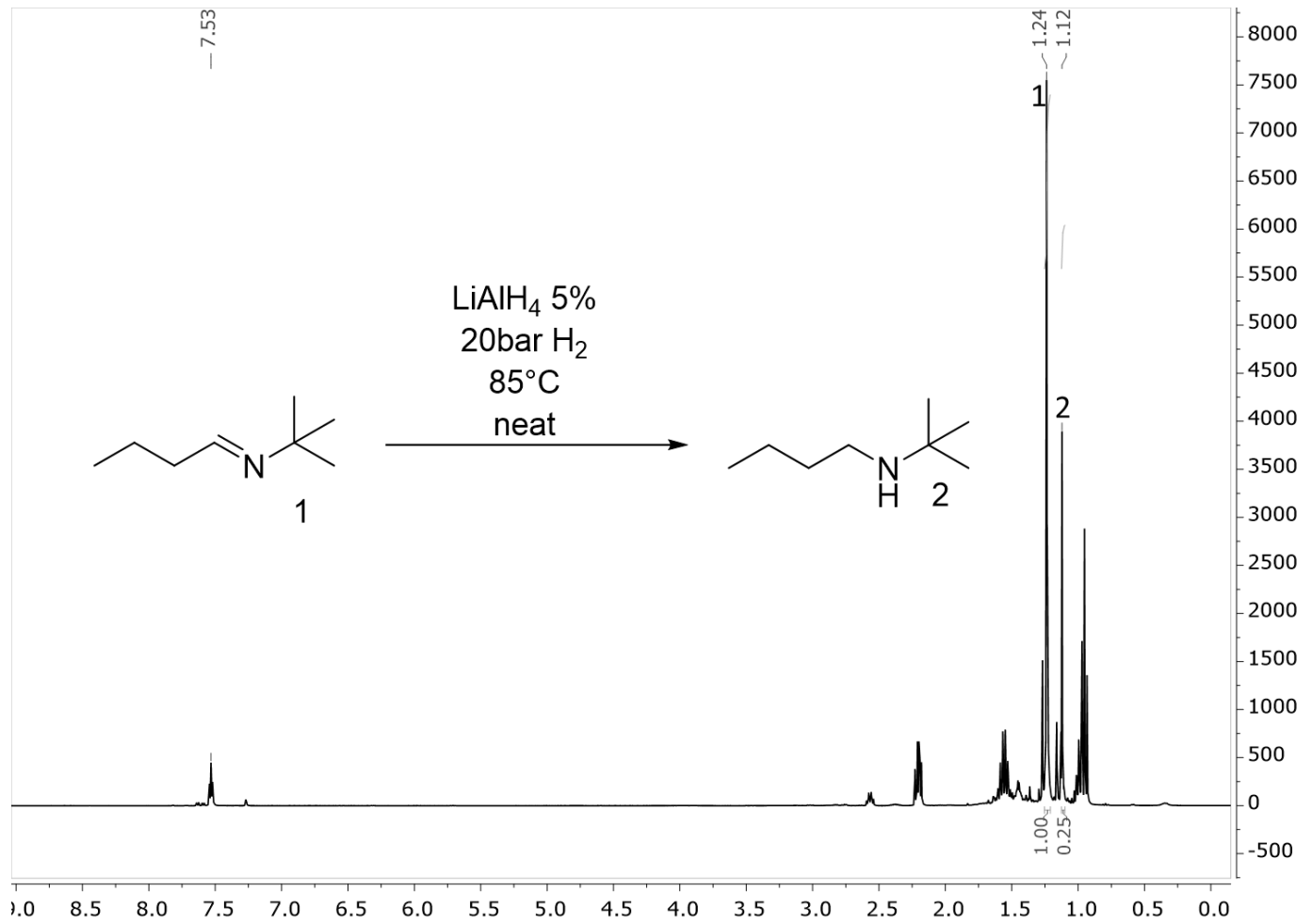

Fig. S26: ${ }^{1} \mathrm{H}$ NMR spectrum for the reaction of $n \mathrm{Bu}(\mathrm{CH})=\mathrm{NtBu}$ with $\mathrm{LiAlH}_{4}(5 \%)$ at 20 bar $\mathrm{H}_{2}$ at $85^{\circ} \mathrm{C}$ for $24 \mathrm{~h}$ in $\mathrm{C}_{6} \mathrm{D}_{6}$. 


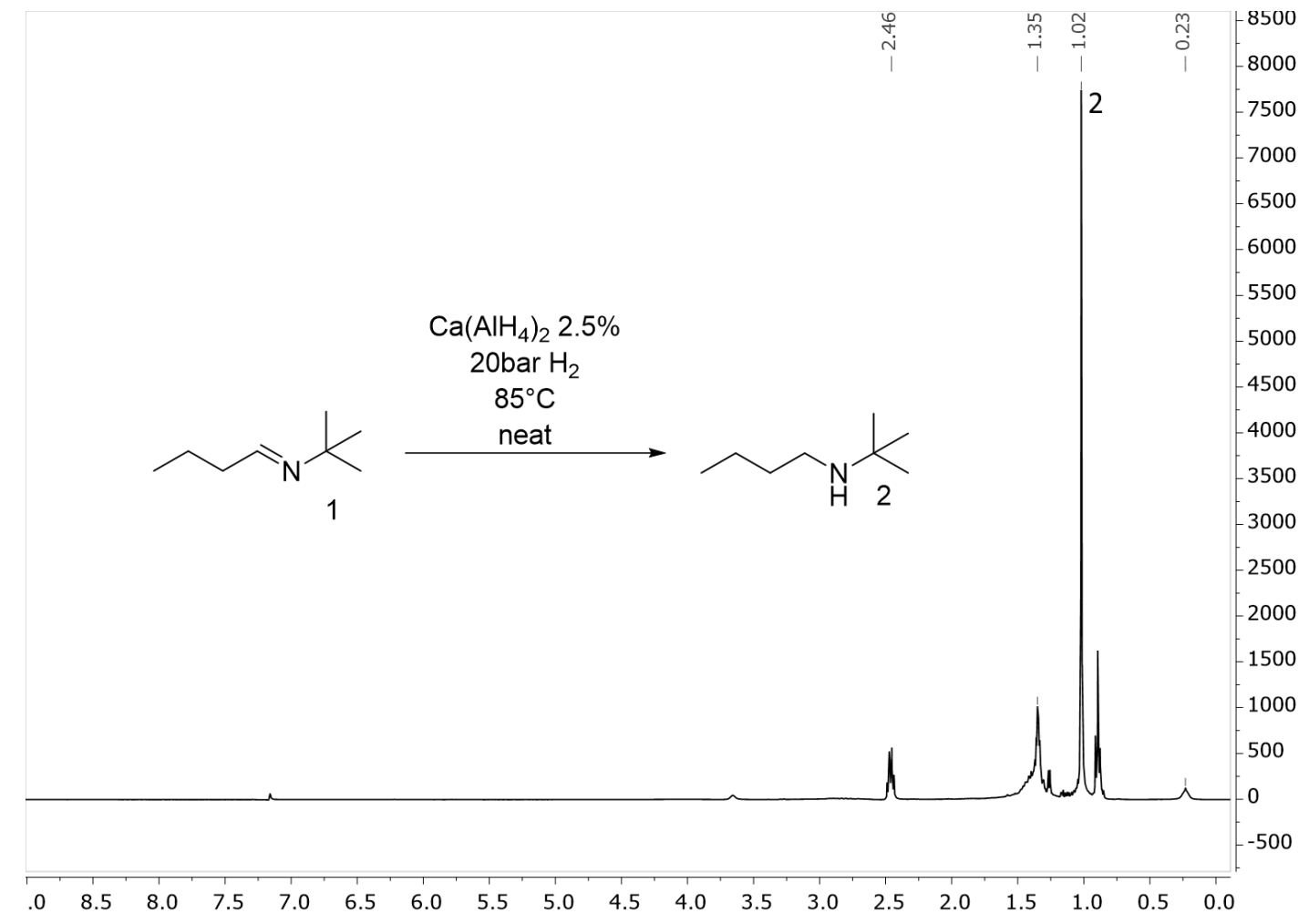

Fig. S27: ${ }^{1} \mathrm{H}$ NMR spectrum for the reaction of $n \mathrm{Bu}(\mathrm{CH})=\mathrm{N} t \mathrm{Bu}$ with $\mathrm{Ca}\left(\mathrm{AlH}_{4}\right)_{2} \cdot(\mathrm{THF})_{4}(2.5 \%)$ at 20 bar $\mathrm{H}_{2}$ at $85^{\circ} \mathrm{C}$ for $24 \mathrm{~h}$ in $\mathrm{C}_{6} \mathrm{D}_{6}$.

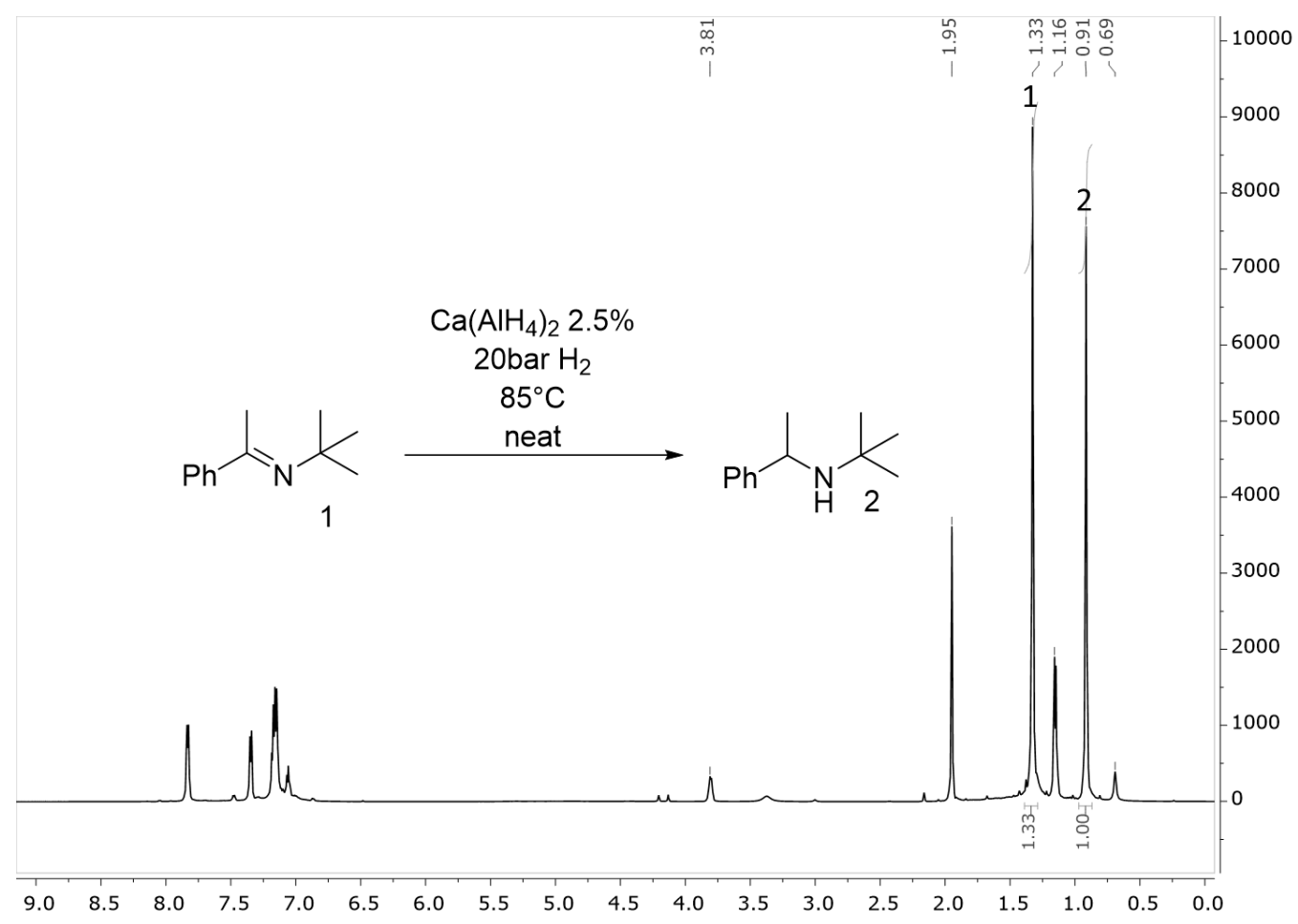

Fig. S28: ${ }^{1} \mathrm{H}$ NMR spectrum for the reaction of $\mathrm{PhC}(\mathrm{Me})=\mathrm{NtBu}$ with $\mathrm{Ca}\left(\mathrm{AlH}_{4}\right)_{2} \cdot(\mathrm{THF})_{4}(2.5 \%)$ at 20 bar $\mathrm{H}_{2}$ at $85^{\circ} \mathrm{C}$ for $24 \mathrm{~h}$ in $\mathrm{C}_{6} \mathrm{D}_{6}$. 


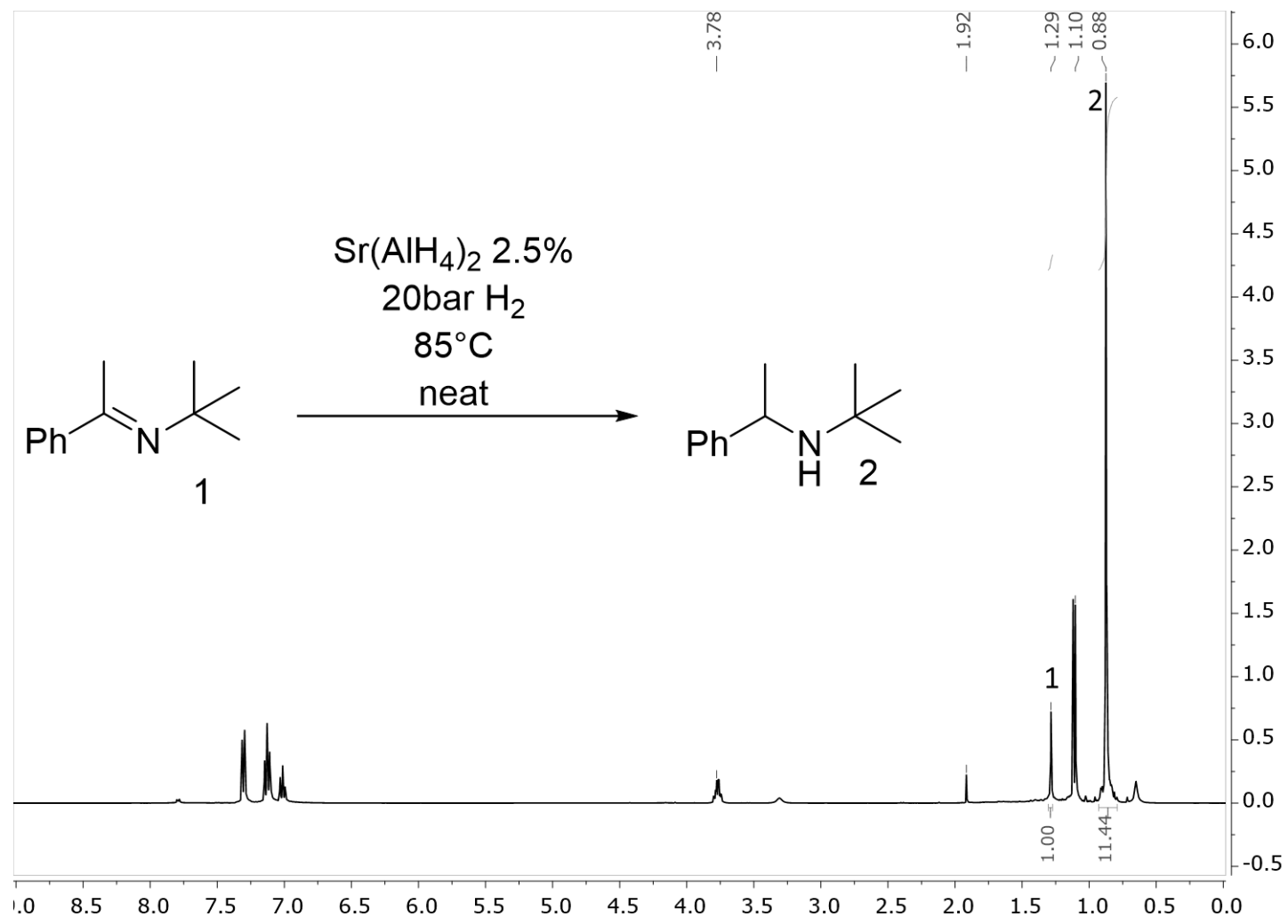

Fig. S29: ${ }^{1} \mathrm{H}$ NMR spectrum for the reaction of $\mathrm{PhC}(\mathrm{Me})=\mathrm{NtBu}$ with $\mathrm{Sr}\left(\mathrm{AlH} \mathrm{H}_{4}\right)_{2} \cdot(\mathrm{THF})_{5}(2.5 \%)$ at 20 bar $\mathrm{H}_{2}$ at $85^{\circ} \mathrm{C}$ for $24 \mathrm{~h}$ in $\mathrm{C}_{6} \mathrm{D}_{6}$. 


\section{Crystal Structure Determination}

\section{Structure determination of $\mathrm{Ca}\left(\mathrm{AlH}_{4}\right)_{2} \cdot(\mathrm{THF})_{4}$}

A colorless crystal of compound $\mathrm{Ca}\left(\mathrm{AlH}_{4}\right)_{2} \cdot(\mathrm{THF})_{4}$ was embedded in inert perfluoropolyalkylether (viscosity 1800 cSt; ABCR GmbH) and mounted using a Hampton Research CryoLoop. The crystal was then flash cooled to 99.9(3) K in a nitrogen gas stream and kept at this temperature during the experiment. The crystal structure was measured on a SuperNova diffractometer with Atlas S2 detector using a CuKa microfocus source. The measured data was processed with the CrysAlisPro (v40.53) software package. ${ }^{[11]}$ Using Olex2, ${ }^{\left[{ }^{[52]}\right.}$ the structure was solved with the ShelX ${ }^{[53]}$ structure solution program using Intrinsic Phasing and refined with the ShelX ${ }^{[S 4]}$ refinement package using Least Squares minimization. All non-hydrogen atoms were refined anisotropically. Most hydrogen atoms were placed in ideal positions and refined as riding atoms with relative isotropic displacement parameters. The positions of the aluminum bound hydrides were observed from difference Fourier maps and refined.

Disorder of two THF ligands was observed, and was modeled with the help of similarity restraints (SADI) and a rigid bond restraint (RIGU). ${ }^{[55]}$ The relative occupancies of the two alternative orientations were refined to $0.613(14) / 0.387(14)$ and $0.836(9) / 0.164(9)$, respectively.

The crystal structure data has been deposited with the Cambridge Crystallographic Data Centre. CCDC 1993706 contains the supplementary crystallographic data for complex $\mathrm{Ca}\left(\mathrm{AlH}_{4}\right)_{2} \cdot(\mathrm{THF})_{4}$. This data can be obtained free of charge from The Cambridge Crystallographic Data Centre via www.ccdc.cam.ac.uk/data request/cif.

Crystallographic and refinement data are summarized in Table S1.

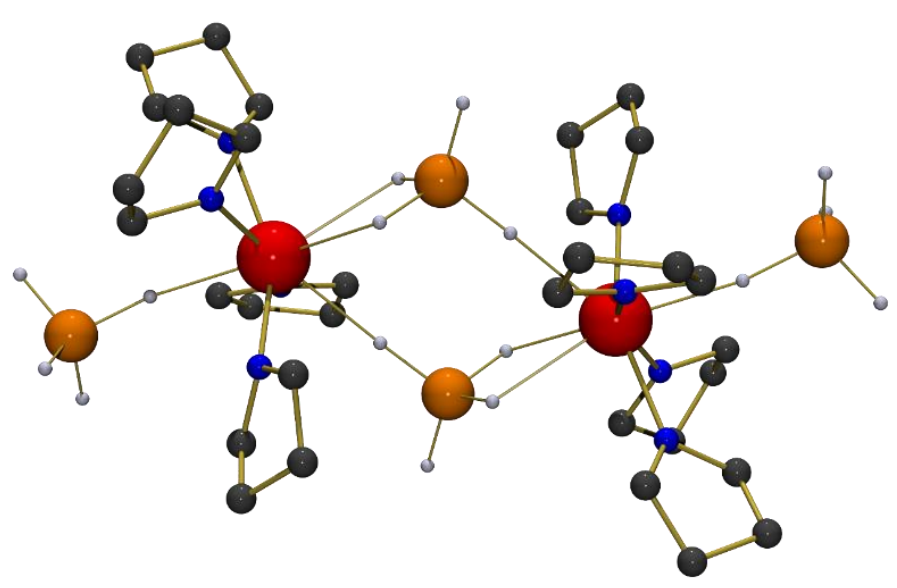

Fig. S30: Dimeric connectivity for $\mathrm{Ca}\left(\mathrm{AlH}_{4}\right)_{2} \cdot(\mathrm{THF})_{4}$. The Al-H $\cdots \mathrm{Ca}$ ' bridge to the neighboring monomer measures 2.43(3) A. 


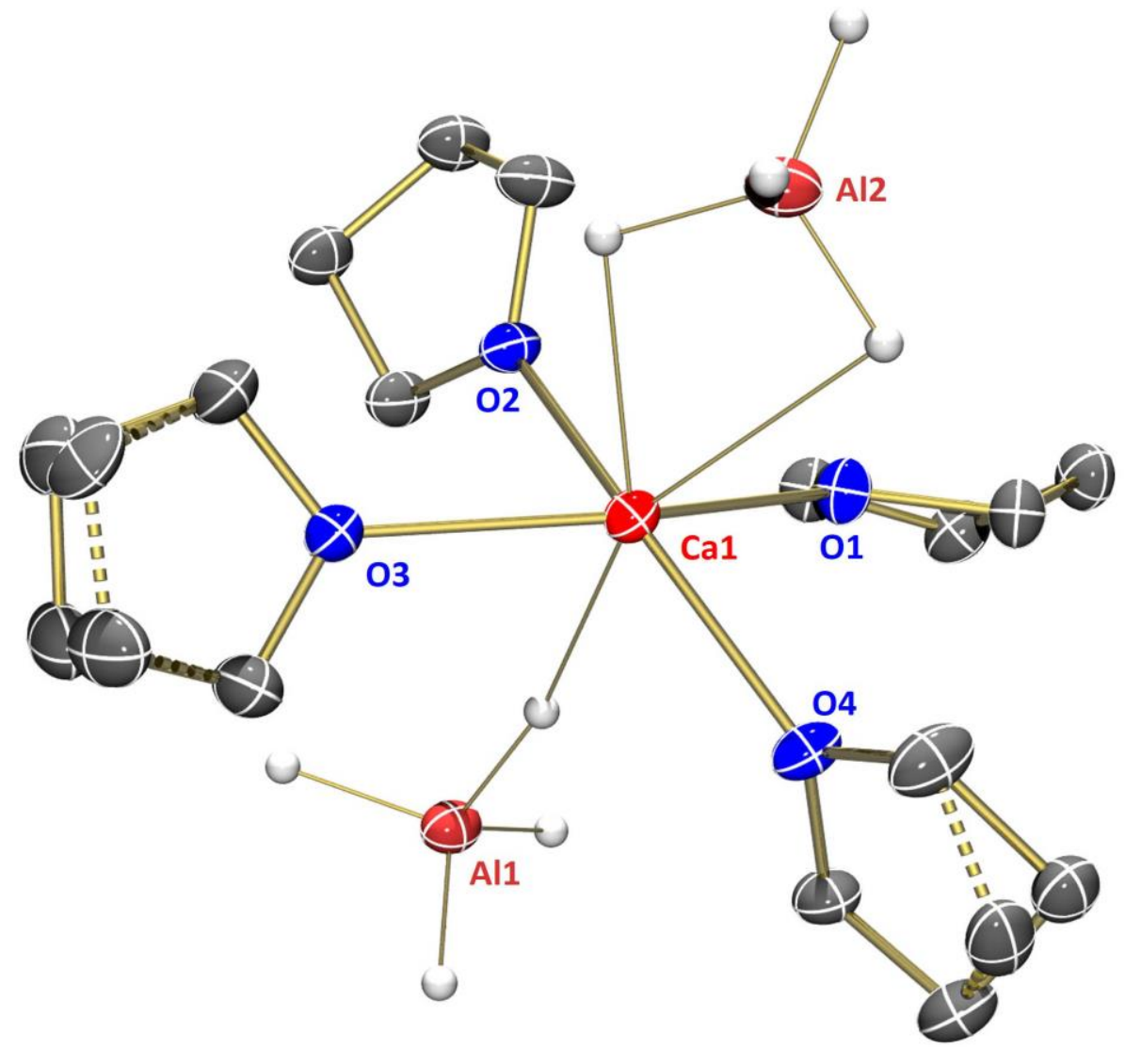

Fig. S31: ORTEP-plot (50\% probability) for $\mathrm{Ca}\left(\mathrm{AlH}_{4}\right)_{2} \cdot(\mathrm{THF})_{4} ; \mathrm{H}$ atoms except for those bound to Al are omitted for clarity. 


\section{Structure determination of $\left.\mathrm{Sr}_{(\mathrm{AlH}}\right)_{2} \cdot(\mathrm{THF})_{5}$}

A colorless crystal of compound $\mathrm{Sr}\left(\mathrm{AlH}_{4}\right)_{2} \cdot(\mathrm{THF})_{5}$ was embedded in inert perfluoropolyalkylether (viscosity 1800 cSt; ABCR GmbH) and mounted using a Hampton Research CryoLoop. The crystal was then flash cooled to $100.0(5) \mathrm{K}$ in a nitrogen gas stream and kept at this temperature during the experiment. The crystal structure was measured on a SuperNova diffractometer with Atlas S2 detector using a MoKa microfocus source. The measured data was processed with the CrysAlisPro (v38.46) software package. ${ }^{[56]}$ Using Olex2, ${ }^{[52]}$ the structure was solved with the ShelX ${ }^{[53]}$ structure solution program using Intrinsic Phasing and refined with the ShelXL ${ }^{[54]}$ refinement package using Least Squares minimization. All non-hydrogen atoms were refined anisotropically. Most hydrogen atoms were placed in ideal positions and refined as riding atoms with relative isotropic displacement parameters. The positions of the aluminum bound hydrides were observed from difference Fourier maps and refined.

Disorder of four THF ligands was observed, and was modeled with the help of similarity restraints (SADI, SIMU). The relative occupancies of the two alternative orientations were refined to $0.60(2) / 0.40(2)$, $0.504(14) / 0.496(14), 0.689(8) / 0.311(8)$ and $0.73(2) / 0.27(2)$, respectively.

The crystal structure data has been deposited with the Cambridge Crystallographic Data Centre. CCDC 1993707 contains the supplementary crystallographic data for complex $\operatorname{Sr}\left(\mathrm{AlH}_{4}\right)_{2} \cdot(\mathrm{THF})_{5}$. This data can be obtained free of charge from The Cambridge Crystallographic Data Centre via www.ccdc.cam.ac.uk/data request/cif.

Crystallographic and refinement data are summarized in Table S1.

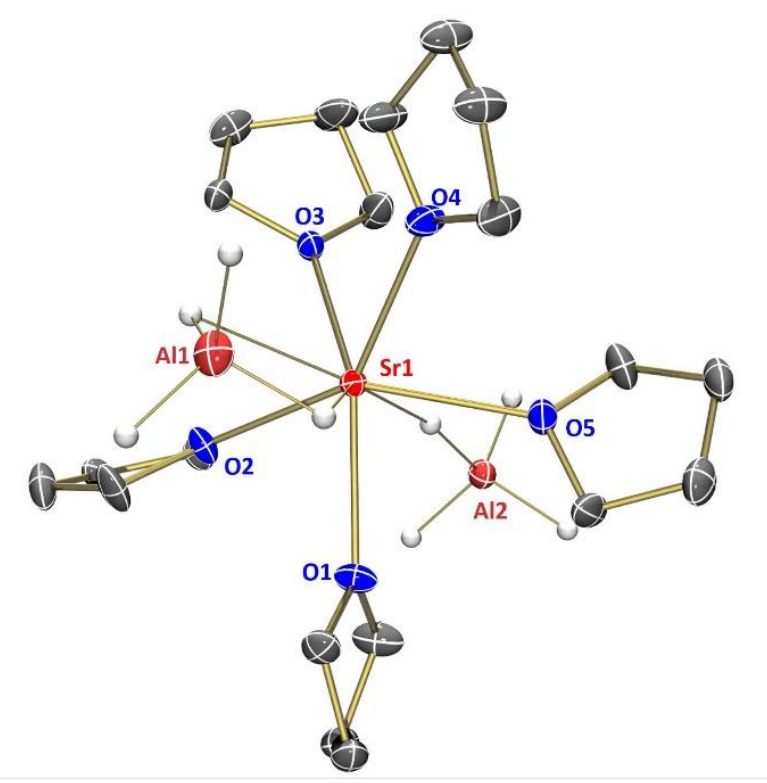

Fig. S32: ORTEP-plot (50\% probability) for $\mathrm{Sr}\left(\mathrm{AlH}_{4}\right)_{2} \cdot(\mathrm{THF})_{5} ; \mathrm{H}$ atoms except for those bound to Al are omitted for clarity. 


\section{Structure determination of ( $\left.{ }^{\mathrm{DIPP}} \mathrm{BDI}\right) \mathrm{Mg}\left(\mathrm{AlH}_{4}\right) \cdot \mathrm{THF}$}

A colorless plate of compound ( $\left.{ }^{\mathrm{DIP}} \mathrm{BDI}\right) \mathrm{Mg}\left(\mathrm{AlH}_{4}\right) \cdot(\mathrm{THF})$ was embedded in inert perfluoropolyalkylether (viscosity 1800 cSt; ABCR GmbH) and mounted using a Hampton Research CryoLoop. The crystal was then flash cooled to $100.0(1) \mathrm{K}$ in a nitrogen gas stream and kept at this temperature during the experiment. The crystal structure was measured on a SuperNova diffractometer with Atlas S2 detector using a CuKa microfocus source. The crystal under investigation was a non-merohedral twin. The measured data was processed accordingly with the CrysAlisPro (v40.18b) software package. ${ }^{[57]}$ Using Olex2, ${ }^{[52]}$ the structure was solved with the ShelXT ${ }^{[S 3]}$ structure solution program using Intrinsic Phasing and refined with the ShelXL ${ }^{\left[{ }^{[S 4]}\right.}$ refinement package using Least Squares minimization. All non-hydrogen atoms were refined anisotropically. Most hydrogen atoms were placed in ideal positions and refined as riding atoms with relative isotropic displacement parameters. The positions of the hydrides were observed from difference Fourier maps and refined. Al-H distances were restrained to be similar in each $\mathrm{AlH}_{4}$ moiety (SADI). Disorder of one THF ligand was observed, and was modeled with the help of similarity restraints (SIMU, SADI) and rigid bond restraints (RIGU). ${ }^{[55]}$ The relative occupancies of the two alternative orientations were refined to $0.660(8)$ and $0.340(8)$. Once a sensible model had been established, final refinement cycles were performed using the HKLF5 reflection file. The fractional contribution of the two twin domains was refined to 0.5545(12) and 0.4455(12), respectively. The crystal structure data has been deposited with the Cambridge Crystallographic Data Centre. CCDC 1993708 contains the supplementary crystallographic data for complex ( $\left.{ }^{\mathrm{DIPP}} \mathrm{BDI}\right) \mathrm{Mg}\left(\mathrm{AlH}_{4}\right) \cdot(\mathrm{THF})$. This data can be obtained free of charge from The Cambridge Crystallographic Data Centre via www.ccdc.cam.ac.uk/data request/cif. Crystallographic and refinement data are summarized in Table S1.

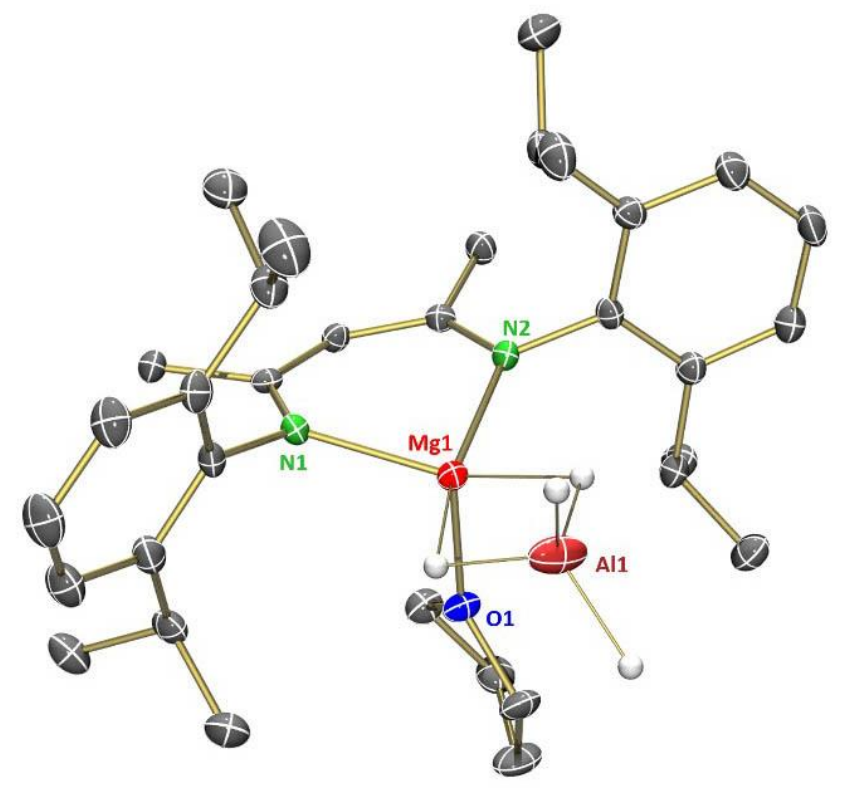

Fig. S33: ORTEP-plot (50\% probability) for ( $\left.{ }^{\mathrm{DIPP}} \mathrm{BDI}\right) \mathrm{Mg}\left(\mathrm{AlH}_{4}\right) \cdot(\mathrm{THF}) ; \mathrm{H}$ atoms except for those bound to Al are omitted for clarity. 


\section{Structure determination of ( $\left.{ }^{\mathrm{DIPP}} \mathrm{BDI}\right) \mathrm{Ca}\left(\mathrm{AlH} \mathrm{H}_{4}\right) \cdot(\mathrm{THF})_{2}$}

A colorless crystal of compound ( $\left.{ }^{\mathrm{DIPP}} \mathrm{BDI}\right) \mathrm{Ca}\left(\mathrm{AlH} \mathrm{H}_{4}\right) \cdot(\mathrm{THF})_{2}$ was embedded in inert perfluoropolyalkylether (viscosity 1800 cSt; ABCR GmbH) and mounted using a Hampton Research CryoLoop. The crystal was then flash cooled to $100.0(1) \mathrm{K}$ in a nitrogen gas stream and kept at this temperature during the experiment. The crystal structure was measured on a SuperNova diffractometer with Atlas S2 detector using a CuKa microfocus source. The measured data was processed with the CrysAlisPro (v39.46) software package. ${ }^{\text {[88] }}$ Using Olex2 ${ }^{[52]}$, the structure was solved with the ShelXX ${ }^{[33]}$ structure solution program using Intrinsic Phasing and refined with the ShelXL ${ }^{[54]}$ refinement package using Least Squares minimization. All non-hydrogen atoms were refined anisotropically. Most hydrogen atoms were placed in ideal positions and refined as riding atoms with relative isotropic displacement parameters. The positions of the aluminum bound hydrides and of $\mathrm{H} 3$ were observed from difference Fourier maps and refined.

The crystal structure data has been deposited with the Cambridge Crystallographic Data Centre. CCDC 1993709 contains the supplementary crystallographic data for complex ( $\left.{ }^{\mathrm{DIPP}} \mathrm{BDI}\right) \mathrm{Ca}\left(\mathrm{AlH} \mathrm{H}_{4}\right) \cdot(\mathrm{THF})_{2}$. This data can be obtained free of charge from The Cambridge Crystallographic Data Centre via www.ccdc.cam.ac.uk/data request/cif.

Crystallographic and refinement data are summarized in Table S1.

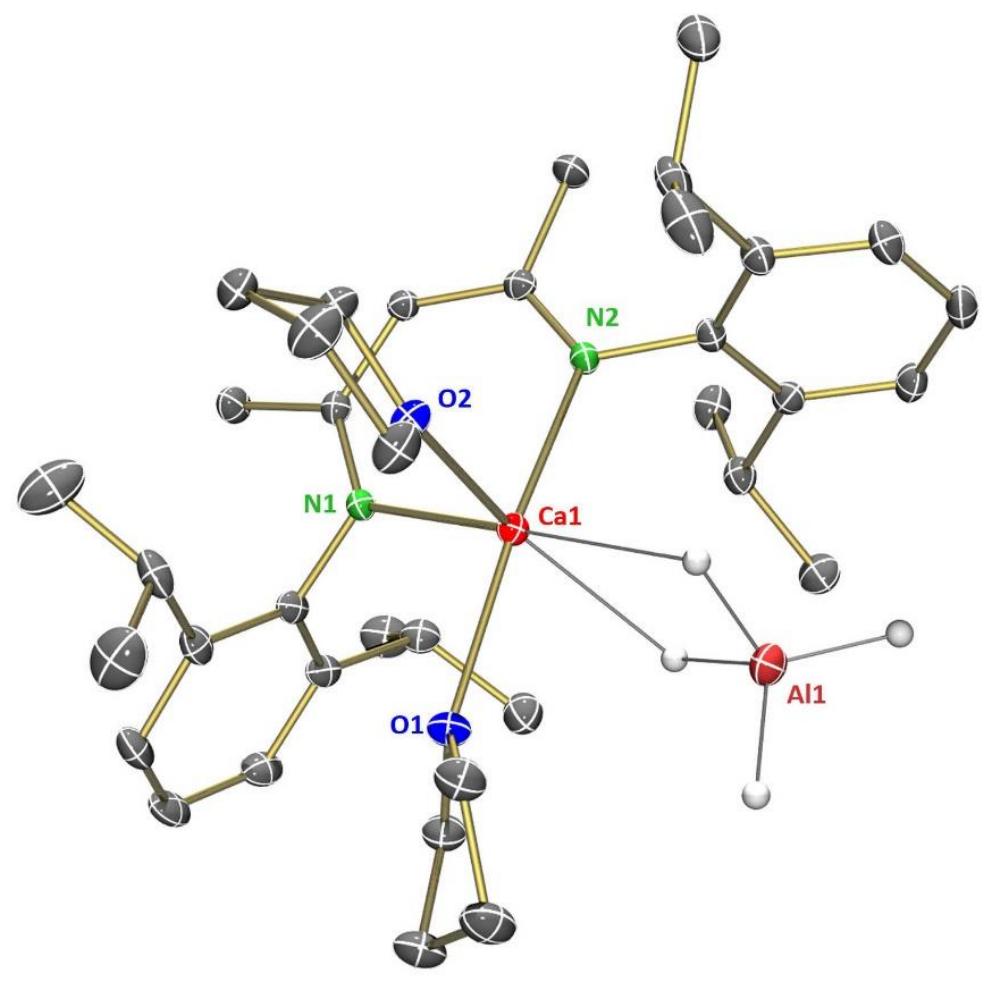

Fig. S34: ORTEP-plot (50\% probability) for $\left({ }^{\mathrm{DIPP}} \mathrm{BDI}\right) \mathrm{Ca}(\mathrm{AlH} 4) \cdot(\mathrm{THF})_{2} ; \mathrm{H}$ atoms except for those bound to Al are omitted for clarity. 


\section{Structure determination of $\left({ }^{\mathrm{DIPP}} \mathrm{BDI}\right) \mathrm{Ca}[\mathrm{N}(\mathrm{tBu})(\mathrm{HC}=\mathrm{C}(\mathrm{H}) \mathrm{Et})] \cdot \mathrm{THF}$}

A colorless crystal (thin plate) of compound ( ${ }^{\mathrm{DIPP} B D I)} \mathrm{Ca}[\mathrm{N}(\mathrm{tBu})(\mathrm{HC}=\mathrm{C}(\mathrm{H}) \mathrm{Et})] \cdot \mathrm{THF}$ was embedded in inert perfluoropolyalkylether (viscosity $1800 \mathrm{cSt}$; ABCR GmbH) and mounted using a Hampton Research CryoLoop. The crystal was then flash cooled to $100.0(3) \mathrm{K}$ in a nitrogen gas stream and kept at this temperature during the experiment. The crystal structure was measured on a SuperNova diffractometer with Atlas S2 detector using a CuKa microfocus source. The crystal under investigation was a non-merohedral twin. The measured data was processed accordingly with the CrysAlisPro (v40.53) software package. ${ }^{[11]}$ Using Olex2, ${ }^{\left[{ }^{[52]}\right.}$ the structure was solved with the ShelXT ${ }^{[33]}$ structure solution program using Intrinsic Phasing and refined with the ShelXL ${ }^{[S 4]}$ refinement package using Least Squares minimization. All non-hydrogen atoms were refined anisotropically. Most hydrogen atoms were placed in ideal positions and refined as riding atoms with relative isotropic displacement parameters. The positions of the hydrogen atom at C30 and C31 were observed from difference Fourier maps and refined. Disorder of the tert-butyl group and of one isopropyl group was observed, and was modeled with the help of similarity restraints (SIMU, SADI) as well as rigid bond restraints $(\mathrm{RIGU})^{[\mathrm{S13}]}$. The relative occupancies of the two alternative orientations were refined to $0.917(6) / 0.083(6)$ $(t \mathrm{Bu})$ and $0.812(17) / 0.188(17)(i-\mathrm{Pr})$, respectively. Once a sensible model had been established, final refinement cycles were performed using the HKLF5 reflection file. The fractional contribution of the two twin domains was refined to $0.5545(12)$ and $0.4455(12)$, respectively.

The crystal structure data has been deposited with the Cambridge Crystallographic Data Centre. CCDC 1993710 contains the supplementary crystallographic data for complex $\left.{ }^{\text {DIPP }} \mathrm{BDI}\right) \mathrm{Ca}[\mathrm{N}(\mathrm{tBu})(\mathrm{HC}=\mathrm{C}(\mathrm{H}) \mathrm{Et})] \cdot \mathrm{THF}$ This data can be obtained free of charge from The Cambridge Crystallographic Data Centre via www.ccdc.cam.ac.uk/data request/cif. Crystallographic and refinement data are summarized in Table S1.

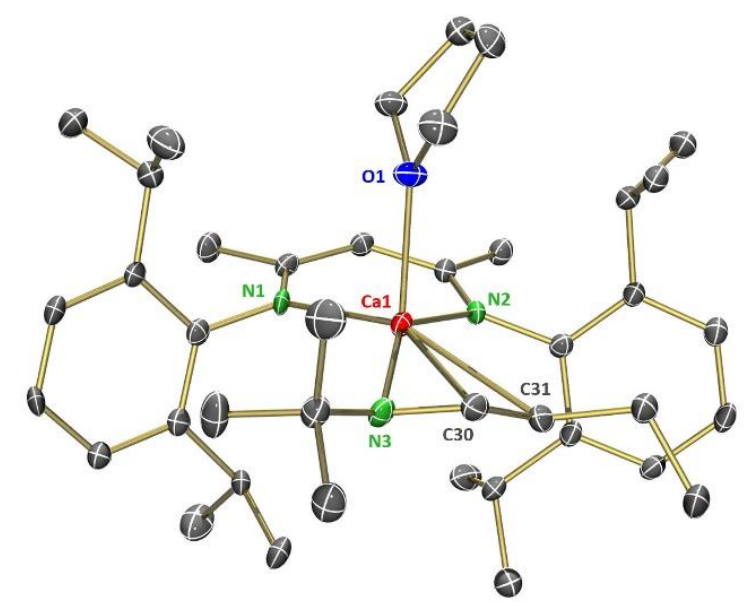

Fig. S35: ORTEP-plot (50\% probability) for ( $\left.{ }^{\mathrm{DIPP}} \mathrm{BDI}\right) \mathrm{Ca}[\mathrm{N}(\mathrm{tBu})(\mathrm{HC}=\mathrm{C}(\mathrm{H}) \mathrm{Et})] \cdot \mathrm{THF} ; \mathrm{H}$ atoms except for those bound to Al are omitted for clarity. 
Structure determination of the decomposition product of $\left({ }^{\mathrm{DIPP}} \mathrm{BDI}\right) \mathrm{Ca}\left(\mathrm{AlH}_{4}\right) \cdot(\mathrm{THF})_{2}$ : $\left[\mathrm{Ca}(\text { thf })_{6}\right]\left[\left\{\mathrm{DippNC}(\mathrm{Me}) \mathrm{CHCH}(\mathrm{Me}) \mathrm{NDipp}_{\left.\mathrm{A} A \mathrm{H}_{2}\right]_{2} \cdot 2 \mathrm{THF}}\right.\right.$

A colorless needle of compound $\left[\mathrm{Ca}(\text { thf })_{6}\right]\left[\left\{\mathrm{DippNC}(\mathrm{Me}) \mathrm{CHCH}(\mathrm{Me}) \mathrm{NDipp}_{\mathrm{A}} \mathrm{AlH}_{2}\right]_{2} \cdot 2 \mathrm{THF}\right.$ was embedded in inert perfluoropolyalkylether (viscosity $1800 \mathrm{cSt}$; ABCR GmbH) and mounted using a Hampton Research CryoLoop. The crystal was then flash cooled to $153.0(2) \mathrm{K}$ in a nitrogen gas stream and kept at this temperature during the experiment. The crystal structure was measured on a SuperNova diffractometer with Atlas detector using a CuKa microfocus source. The measured data was processed with the CrysAlisPro (v39.46) software package. ${ }^{[51]}$ Using Olex2 ${ }^{[52]}$, the structure was solved with the ShelXT ${ }^{[53]}$ structure solution program using Intrinsic Phasing and refined with the SheIXL ${ }^{[54]}$ refinement package using Least Squares minimization. All non-hydrogen atoms were refined anisotropically. Most hydrogen atoms were placed in ideal positions and refined as riding atoms with relative isotropic displacement parameters. The positions of the aluminum bound hydrides were observed from difference Fourier maps and refined.

The structure suffers from massive disorder of cation and anion as well. This disorder is likely the result of the asymmetric nature of the reduced ${ }^{\mathrm{Dipp}} \mathrm{BDI}$ ligand. The backbone of this $\operatorname{DippNC}(\mathrm{Me}) \mathrm{CHCH}(\mathrm{Me}) \mathrm{NDipp}$ ligand adopts four different, overlapping orientations. A reasonable model for this disorder could only be built with a substantial amount of restraints (SADI, SIMU, RIGU, ${ }^{\left[{ }^{[5]}\right]}$ DFIX) and constraints (EADP). Although the final

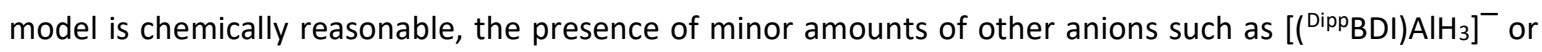
[\{DippNCH(Me) $\left.\left.\mathrm{CH}_{2} \mathrm{CH}(\mathrm{Me}) \mathrm{NDipp}\right) \mathrm{AlH}_{2}\right]^{-}$cannot be excluded safely and the restraints/constraints used prevent a meaningful discussion of bond lengths and angles of this structure.

Therefore, we will not deposit the crystal structure data with the Cambridge Crystallographic Data Centre. Instead, only the connectivity of the molecule is reported (see Figure S36) and the details about structure determination and refinement are included in Table S1. 

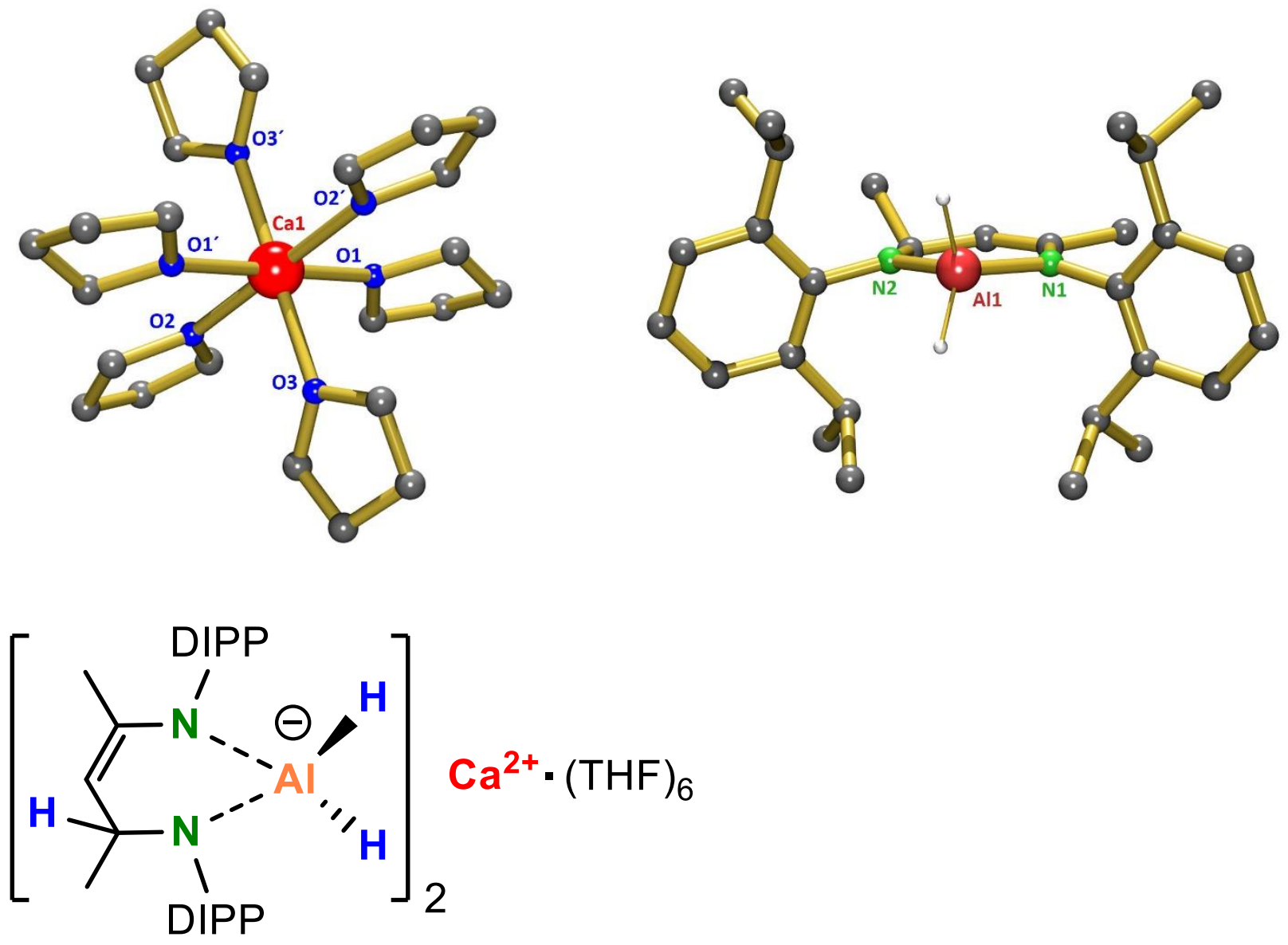

Fig. S36: Ball-and-stick plot for the decomposition product of $\left({ }^{\mathrm{DIPP}} \mathrm{BDI}\right) \mathrm{Ca}\left(\mathrm{AlH} \mathrm{H}_{4}\right) \cdot(\mathrm{THF})_{2} ; \mathrm{H}$ atoms except for those bound to Al are omitted for clarity.

Table S1: Crystallographic data and structure refinement.

\begin{tabular}{cccc}
\hline Compound & $\mathrm{Ca}\left(\mathrm{AlH}_{4}\right)_{2} \cdot(\mathrm{THF})_{4}$ & $\left.\mathrm{Sr}(\mathrm{AlH})_{4} \cdot\right)_{2} \cdot(\mathrm{THF})_{5}$ & $\left.\left({ }^{\text {(IPP }} \mathrm{BDI}\right) \mathrm{Mg}(\mathrm{AlH})_{4}\right) \cdot \mathrm{THF}$ \\
\hline Empirical formula & $\mathrm{C}_{16} \mathrm{H}_{40} \mathrm{Al}_{2} \mathrm{CaO}_{4}$ & $\mathrm{C}_{20} \mathrm{H}_{48} \mathrm{Al}_{2} \mathrm{O}_{5} \mathrm{Sr}$ & $\mathrm{C}_{33} \mathrm{H}_{53} \mathrm{AlMgN}_{2} \mathrm{O}$ \\
Formula weight $\left[\mathrm{g} \mathrm{mol}^{-1}\right]$ & 390.52 & 510.16 & 545.06 \\
\hline
\end{tabular}




\begin{tabular}{|c|c|c|c|}
\hline Temperature $[\mathrm{K}]$ & $99.9(3)$ & $100.0(5)$ & $100.0(1)$ \\
\hline Crystal system & monoclinic & monoclinic & monoclinic \\
\hline Space group & $\mathrm{P} 22_{1} / \mathrm{c}$ & $\mathrm{P} 22_{1} / \mathrm{c}$ & $\mathrm{P} 2{ }_{1} / \mathrm{c}$ \\
\hline $\boldsymbol{a}[\AA ̊]$ & $15.2617(3)$ & $8.7494(2)$ & $17.0855(7)$ \\
\hline $\boldsymbol{b}[\AA]$ & $10.36000(10)$ & $33.9449(6)$ & $20.1326(8)$ \\
\hline $\boldsymbol{c}[\AA \AA]$ & $16.4123(3)$ & $9.5406(2)$ & $19.6109(8)$ \\
\hline$\alpha\left[^{\circ}\right]$ & 90 & 90 & 90 \\
\hline $\boldsymbol{\beta}\left[{ }^{\circ}\right]$ & $115.235(2)$ & $96.018(2)$ & $92.137(4)$ \\
\hline$\gamma\left[{ }^{\circ}\right]$ & 90 & 90 & 90 \\
\hline Volume $\left[\AA^{3}\right]$ & $2347.32(8)$ & $2817.92(10)$ & $6741.0(5)$ \\
\hline z & 4 & 4 & 8 \\
\hline$\rho_{\text {Cald }}\left[\mathrm{g} \mathrm{cm}^{-3}\right]$ & 1.105 & 1.203 & 1.074 \\
\hline $\boldsymbol{\mu}\left[\mathrm{mm}^{-1}\right]$ & 3.139 & 1.999 & 0.888 \\
\hline$F(000)$ & 856.0 & 1088.0 & 2384.0 \\
\hline Crystal size $\left[\mathrm{mm}^{3}\right]$ & $0.326 \times 0.226 \times 0.163$ & $0.284 \times 0.239 \times 0.142$ & $0.442 \times 0.19 \times 0.075$ \\
\hline Radiation & $\operatorname{CuK} \alpha(\lambda=1.54184)$ & $\operatorname{MoK} \alpha(\lambda=0.71073)$ & $\operatorname{CuK} \alpha(\lambda=1.54184)$ \\
\hline $2 \Theta$ range for data collection $\left[^{\circ}\right]$ & 6.402 to 147.588 & 5.906 to 59.624 & 6.294 to 145.432 \\
\hline Index ranges & $\begin{array}{c}-18 \leq h \leq 17,-12 \leq k \leq 12 \\
-20 \leq 1 \leq 19\end{array}$ & $\begin{array}{c}-12 \leq h \leq 11,-42 \leq k \leq 47 \\
-9 \leq 1 \leq 13\end{array}$ & $\begin{array}{c}-21 \leq h \leq 21,-24 \leq k \leq 24, \\
-23 \leq 1 \leq 22\end{array}$ \\
\hline Reflections collected & 25231 & 33007 & 16396 \\
\hline Independent reflections & $\begin{array}{c}4675\left[R_{\text {int }}=0.0410,\right. \\
\left.R_{\text {sigma }}=0.0217\right]\end{array}$ & $\begin{array}{c}7161\left[R_{\text {int }}=0.0369,\right. \\
\left.R_{\text {sigma }}=0.0395\right]\end{array}$ & $\begin{array}{l}16396\left[R_{\text {int }}=?,\right. \\
\left.R_{\text {sigma }}=0.0474\right]\end{array}$ \\
\hline Data / restraints / parameters & $4675 / 30 / 269$ & $7161 / 365 / 370$ & $16396 / 85 / 757$ \\
\hline Goodness-of-fit on $F^{2}$ & 1.050 & 1.114 & 1.046 \\
\hline Final $\mathbf{R}$ indexes $[I \geq 2 \sigma(I)]$ & $\begin{array}{l}\mathrm{R}_{1}=0.0413 \\
\mathrm{wR}=0.1121\end{array}$ & $\begin{aligned} \mathrm{R}_{1} & =0.0418 \\
\mathrm{wR} & =0.0725\end{aligned}$ & $\begin{array}{l}\mathrm{R}_{1}=0.0494 \\
\mathrm{wR}_{2}=0.1232\end{array}$ \\
\hline Final R indexes [all data] & $\begin{array}{c}\mathrm{R}_{1}=0.0449 \\
\mathrm{wR} 2=0.1168\end{array}$ & $\begin{array}{c}\mathrm{R}_{1}=0.0599 \\
\mathrm{w} \mathrm{R}_{2}=0.0776\end{array}$ & $\begin{array}{c}\mathrm{R}_{1}=0.0641 \\
\mathrm{wR} 2=0.1282\end{array}$ \\
\hline Largest diff. peak / hole $\left[e \AA^{-3}\right]$ & $0.46 /-0.37$ & $0.43 /-0.43$ & $0.25 /-0.39$ \\
\hline CCDC number & 1993706 & 1993707 & 1993708 \\
\hline
\end{tabular}


Table S1 (continued): Crystallographic data and structure refinement.

\begin{tabular}{|c|c|c|c|}
\hline Compound & $\mathrm{Ca}\left({ }^{\left({ }^{d i p p} B D I\right)}\left(\mathrm{AlH}_{4}\right)(\text { thf })_{2}\right.$ & $\mathrm{Ca}\left({ }^{\text {dipp } B D I)}\left({ }^{t} \mathrm{BuNCHCHEt}\right)(\right.$ thf $)$ & $\begin{array}{c}{\left[\mathrm{Ca}(\text { thf })_{6}\right]} \\
{[\{\text { DippNC(Me)CHCH(Me)- }} \\
\left.\text { NDipp }\} \mathrm{AlH}_{2}\right]_{2} \cdot 2 \mathrm{THF}\end{array}$ \\
\hline Empirical formula & $\mathrm{C}_{37} \mathrm{H}_{61} \mathrm{AlCaN}_{2} \mathrm{O}_{2}$ & $\mathrm{C}_{41} \mathrm{H}_{65} \mathrm{CaN}_{3} \mathrm{O}$ & $\mathrm{C}_{90} \mathrm{H}_{152} \mathrm{Al}_{2} \mathrm{CaN}_{4} \mathrm{O}_{8}$ \\
\hline Formula weight $\left[\mathrm{g} \mathrm{mol}^{-1}\right]$ & 632.93 & 656.04 & 1512.19 \\
\hline Temperature $[\mathrm{K}]$ & $100.0(1)$ & $100.0(3)$ & $153.0(2)$ \\
\hline Crystal system & orthorhombic & triclinic & monoclinic \\
\hline Space group & Pbca & P-1 & $\mathrm{P} 22_{1} / \mathrm{n}$ \\
\hline $\boldsymbol{a}[\AA \AA]$ & $13.03680(10)$ & $9.1618(15)$ & $13.9849(3)$ \\
\hline $\boldsymbol{b}[\AA ̊ \AA]$ & $15.7278(2)$ & $12.681(2)$ & $17.9431(3)$ \\
\hline $\boldsymbol{c}[\AA ̊]$ & $36.4607(5)$ & $17.539(2)$ & $18.5729(3)$ \\
\hline$\alpha\left[^{\circ}\right]$ & 90 & $78.550(13)$ & 90 \\
\hline $\boldsymbol{\beta}\left[^{\circ}\right]$ & 90 & $81.509(12)$ & $90.223(2)$ \\
\hline$\gamma\left[^{\circ}\right]$ & 90 & $84.737(13)$ & 90 \\
\hline Volume $\left[\AA^{3}\right]$ & 7475.91(15) & $1971.1(5)$ & $4660.51(15)$ \\
\hline z & 8 & 2 & 2 \\
\hline$\rho_{\text {Cald }}\left[\mathrm{g} \mathrm{cm}^{-3}\right]$ & 1.125 & 1.105 & 1.078 \\
\hline $\boldsymbol{\mu}\left[\mathrm{mm}^{-1}\right]$ & 1.909 & 1.608 & 1.161 \\
\hline$F(000)$ & 2768.0 & 720.0 & 1660.0 \\
\hline Crystal size $\left[\mathrm{mm}^{3}\right]$ & $0.333 \times 0.308 \times 0.149$ & $0.195 \times 0.114 \times 0.052$ & $0.42 \times 0.172 \times 0.169$ \\
\hline Radiation & $\operatorname{CuK} \alpha(\lambda=1.54184)$ & $\mathrm{Cu} \mathrm{K \alpha}(\lambda=1.54184)$ & $\mathrm{Cu} K \alpha(\lambda=1.54184)$ \\
\hline $\begin{array}{c}2 \Theta \text { range for data collection } \\
{\left[{ }^{\circ}\right]}\end{array}$ & 8.338 to 147.354 & 7.99 to 145.168 & 6.85 to 145.202 \\
\hline Index ranges & $\begin{array}{c}-15 \leq \mathrm{h} \leq 14,-18 \leq \mathrm{k} \leq \\
19,-37 \leq \mathrm{I} \leq 44\end{array}$ & $\begin{array}{c}-11 \leq h \leq 11,-15 \leq k \leq 15 \\
-20 \leq 1 \leq 21\end{array}$ & $\begin{array}{c}-17 \leq h \leq 14,-21 \leq k \leq 21, \\
-22 \leq 1 \leq 22\end{array}$ \\
\hline Reflections collected & 29596 & 9490 & 33350 \\
\hline Independent reflections & $\begin{array}{c}7317\left[R_{\text {int }}=0.0334\right. \\
\left.R_{\text {sigma }}=0.0321\right]\end{array}$ & $\begin{array}{c}9490\left[R_{\text {int }}=?\right. \\
\left.R_{\text {sigma }}=0.0530\right]\end{array}$ & $\begin{array}{c}9091\left[R_{\text {int }}=0.0244, R_{\text {sigma }}\right. \\
=0.0192]\end{array}$ \\
\hline Data / restraints / parameters & $7317 / 0 / 417$ & $9490 / 278 / 508$ & $9091 / 1366 / 730$ \\
\hline Goodness-of-fit on $\mathrm{F}^{2}$ & 1.064 & 0.972 & 1.059 \\
\hline Final $\mathbf{R}$ indexes $[I \geq 2 \sigma(I)]$ & $\begin{array}{r}\mathrm{R}_{1}=0.0398 \\
\mathrm{wR} \mathrm{R}_{2}=0.0992\end{array}$ & $\begin{array}{r}\mathrm{R}_{1}=0.0631 \\
\mathrm{wR}=0.1613\end{array}$ & $\begin{array}{r}\mathrm{R}_{1}=0.0801 \\
\mathrm{wR}_{2}=0.2042\end{array}$ \\
\hline Final $\mathbf{R}$ indexes [all data] & $\begin{array}{r}\mathrm{R}_{1}=0.0516 \\
\mathrm{wR}\end{array}$ & $\begin{array}{r}\mathrm{R}_{1}=0.0749 \\
\mathrm{wR} \mathrm{R}_{2}=0.1665\end{array}$ & $\begin{array}{r}\mathrm{R}_{1}=0.0886 \\
\mathrm{w} \mathrm{R}_{2}=0.2099\end{array}$ \\
\hline Largest diff. peak / hole $\left[e \AA^{-3}\right]$ & $0.29 /-0.34$ & $0.62 /-0.50$ & $0.41 /-0.34$ \\
\hline CCDC number & 1993709 & 1993710 & Motif (no CCDC deposit) \\
\hline
\end{tabular}




\section{DFT Calculations}

\section{General}

All Calculations were carried out using Gaussian 16A. ${ }^{[59]}$ All Methods were used as implemented. All structures were fully optimized on a B3PW91/def2tzvpp ${ }^{[510-512]}$ level of theory. All structures were characterized as true minima (NIMAG $=0$ ). Charges were calculated using Natural Population Analyses. ${ }^{\text {[\$13] }}$ Molecules were drawn and evaluated using Molecule 2.3. For the QTAIM analysis AIMAll V17 was used. ${ }^{\left[{ }^{[14, S 15]}\right.}$ Wave functions were obtained from the optimizations.

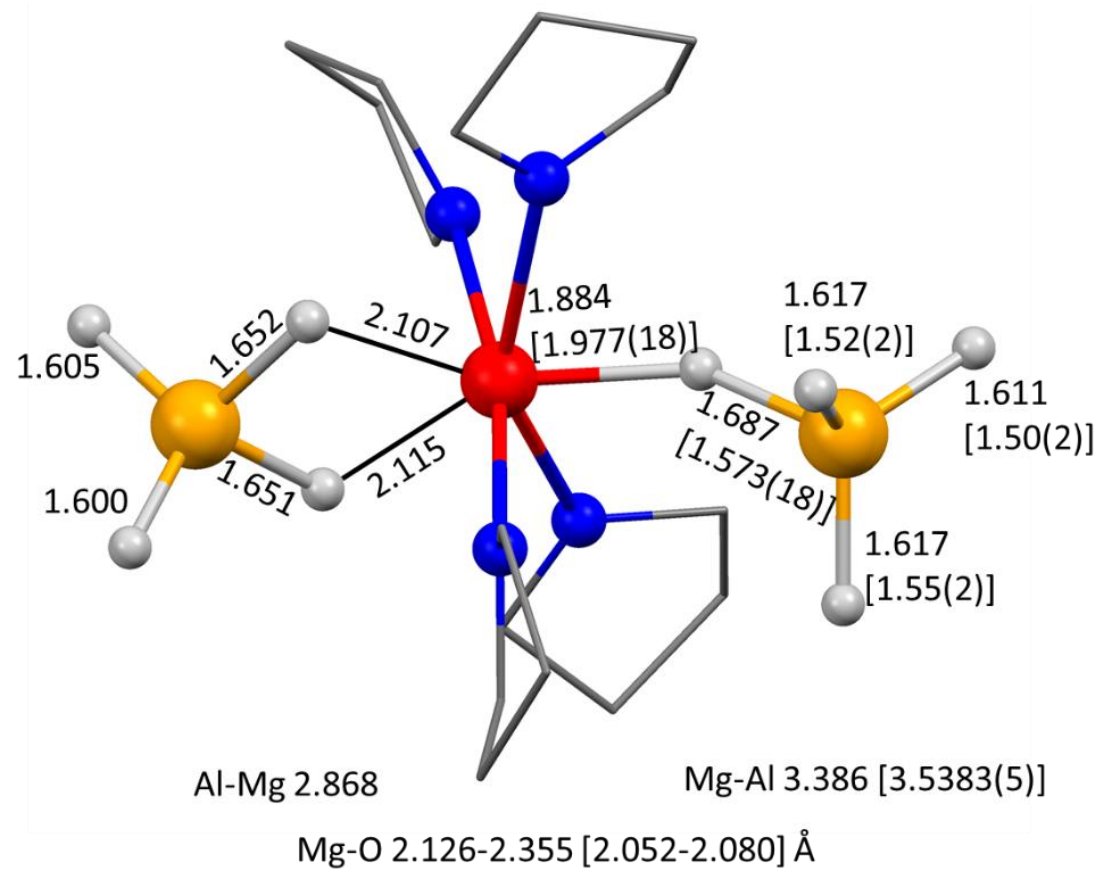

Fig. S37: Calculated bond lengths for $\left.\mathrm{Mg}(\mathrm{AlH})_{4}\right)_{2} \cdot(\mathrm{THF})_{4}$; experimental values from X-ray determination are shown in squared brackets. Note that X-ray diffraction gave a centrosymmetric structure with double $\mathrm{Mg} \cdots \mathrm{H}-\mathrm{AlH}_{3}$ bridging while calculations led to both, $\mathrm{Mg} \cdots \mathrm{HAlH}_{3}$ and $\mathrm{Mg} \cdots \mathrm{H}_{2} \mathrm{AlH}_{2}$ bridging. 


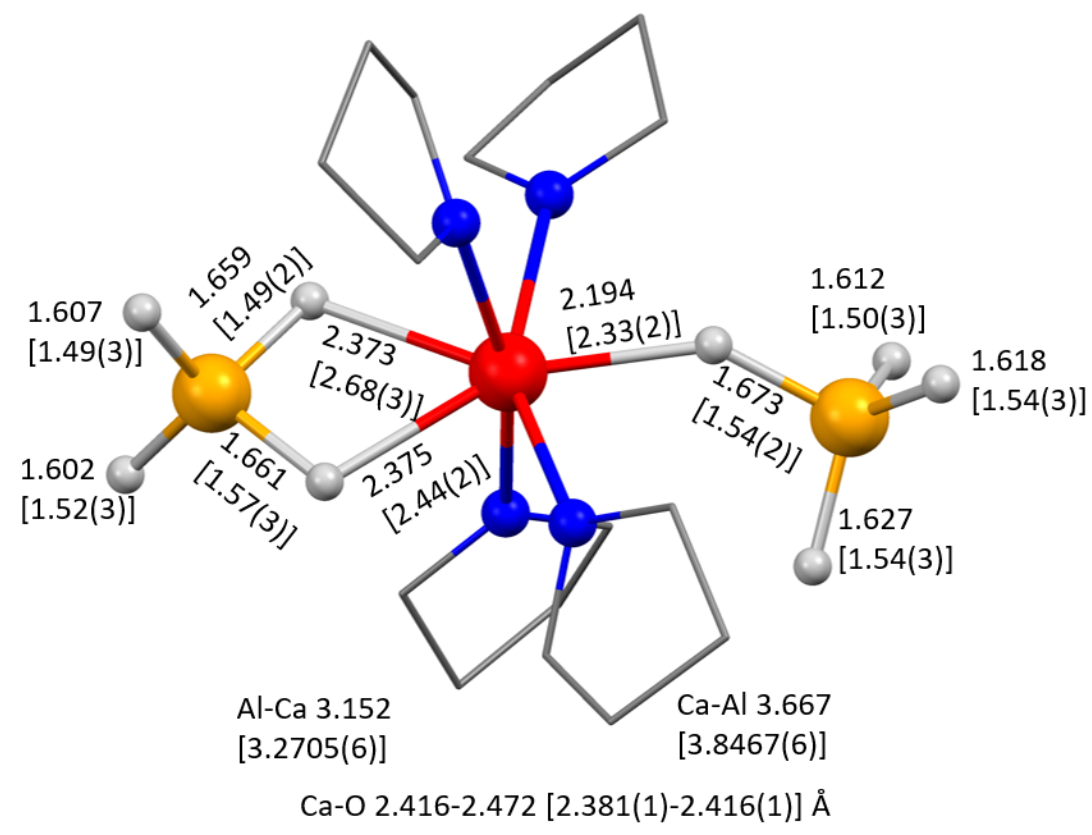

Fig. S38: Calculated bond lengths for $\mathrm{Ca}\left(\mathrm{AlH}_{4}\right)_{2} \cdot(\mathrm{THF})_{4}$; experimental values from X-ray determination are shown in squared brackets.

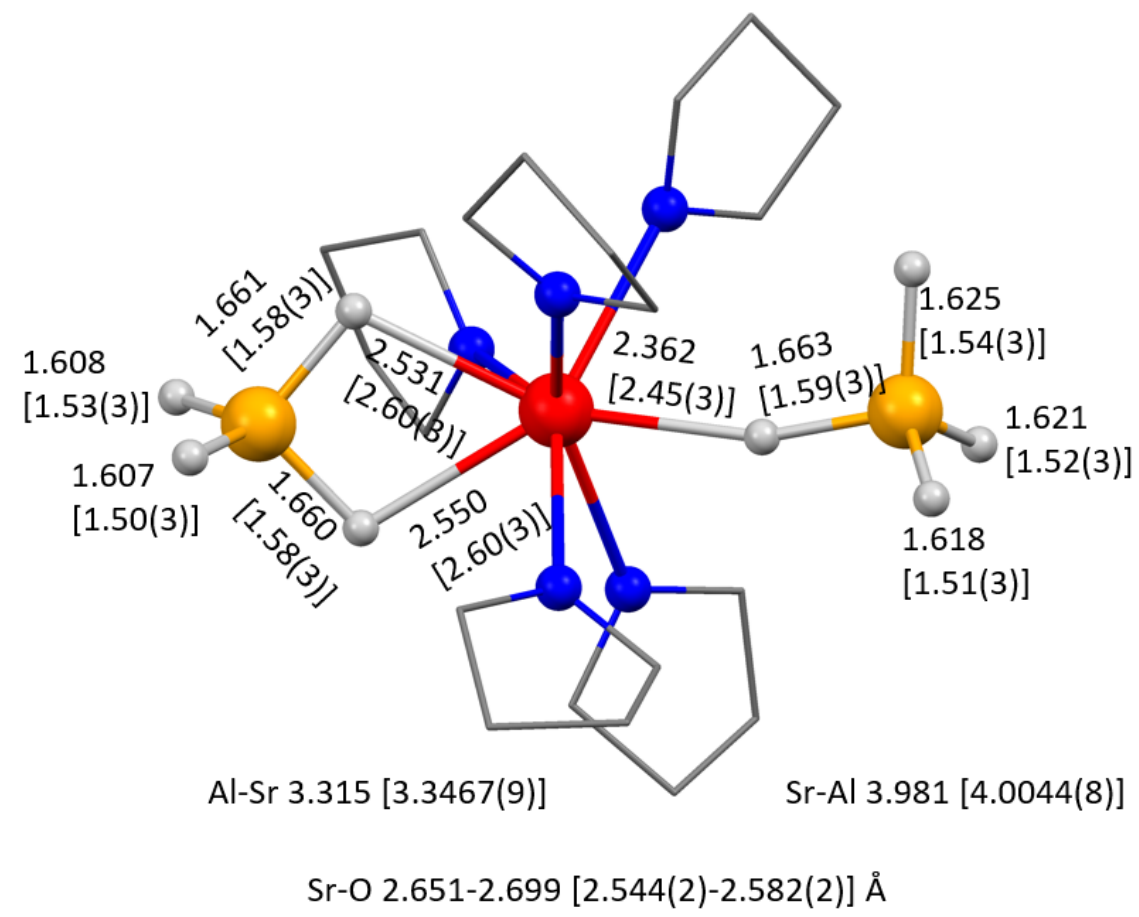

Fig. S39: Calculated bond lengths for $\operatorname{Sr}\left(\mathrm{AlH}_{4}\right)_{2} \cdot(\mathrm{THF})_{5}$; experimental values from $\mathrm{X}$-ray determination are shown in squared brackets. 
AIM

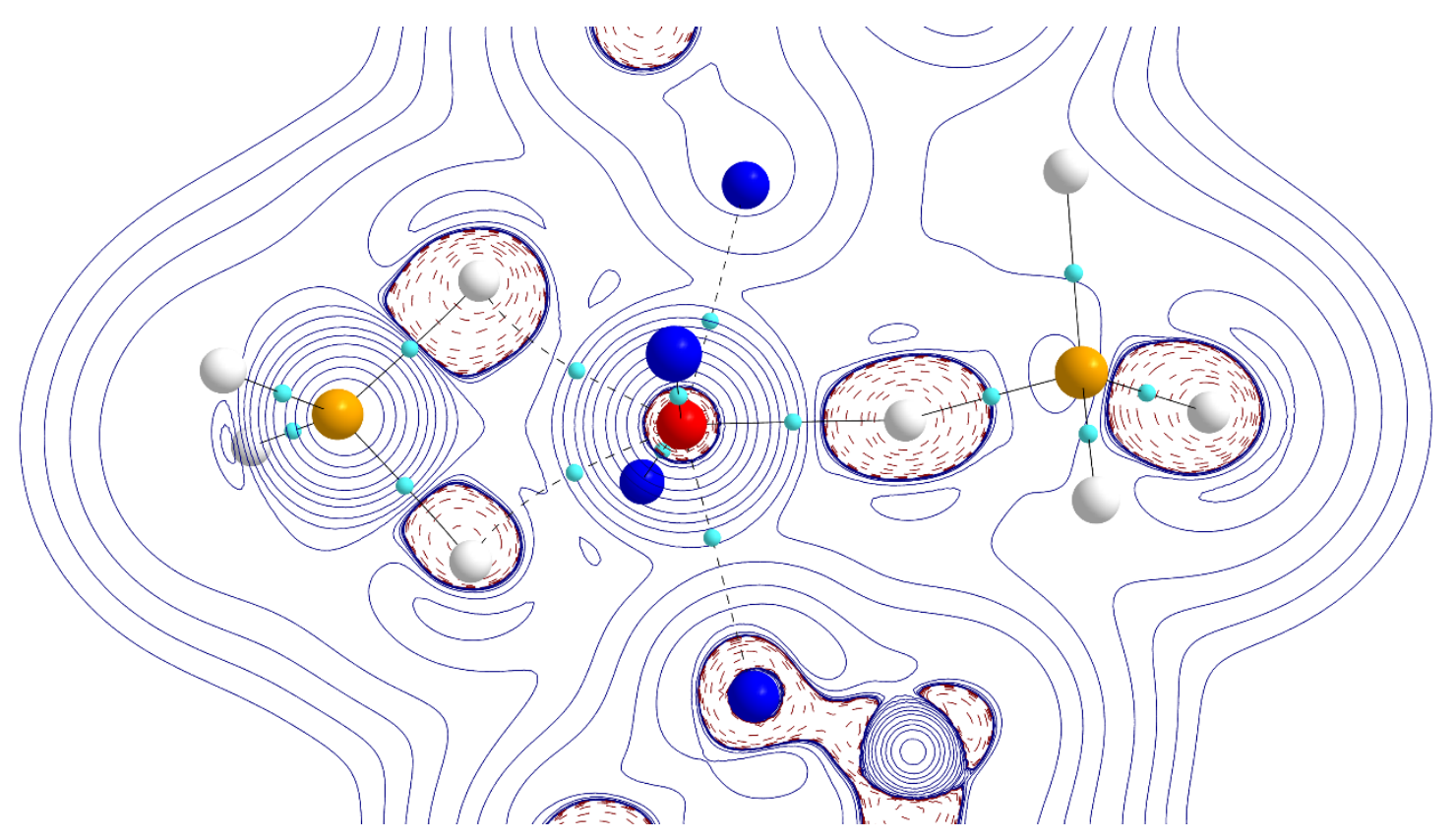

Fig. S40: Laplacian of the electron density in the plane of $[\mathrm{H} ; \mathrm{Mg} ; \mathrm{H}]$ for $\mathrm{Mg}\left(\mathrm{AlH} \mathrm{H}_{4}\right) \cdot(\mathrm{THF})_{4}$. THF omitted for clarity.

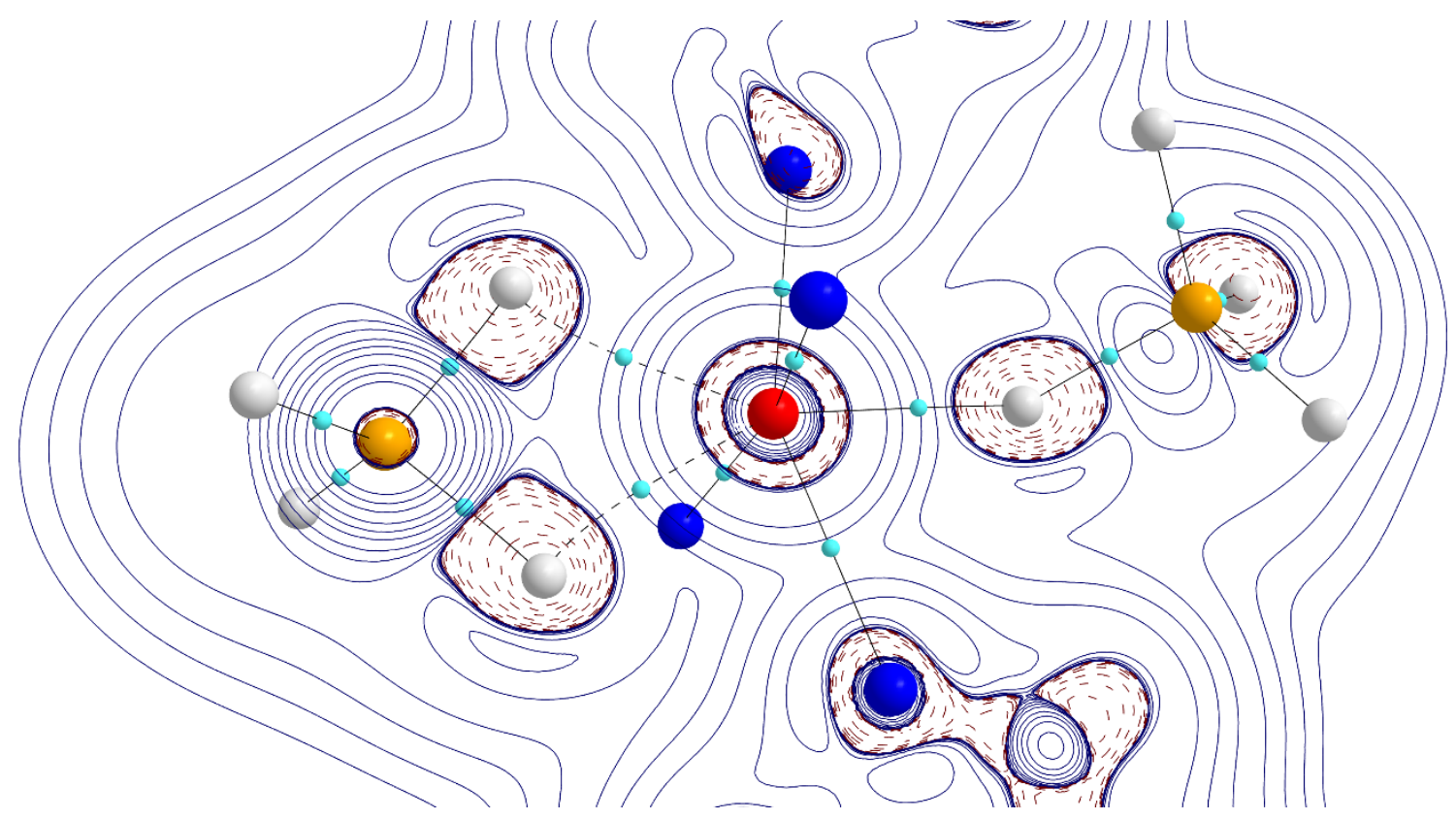

Fig. S41 Laplacian of the electron density in the plane of $[\mathrm{H} ; \mathrm{Ca} ; \mathrm{H}]$ for $\mathrm{Ca}\left(\mathrm{AlH} \mathrm{H}_{4}\right) \cdot(\mathrm{THF})_{4}$. THF omitted for clarity. 


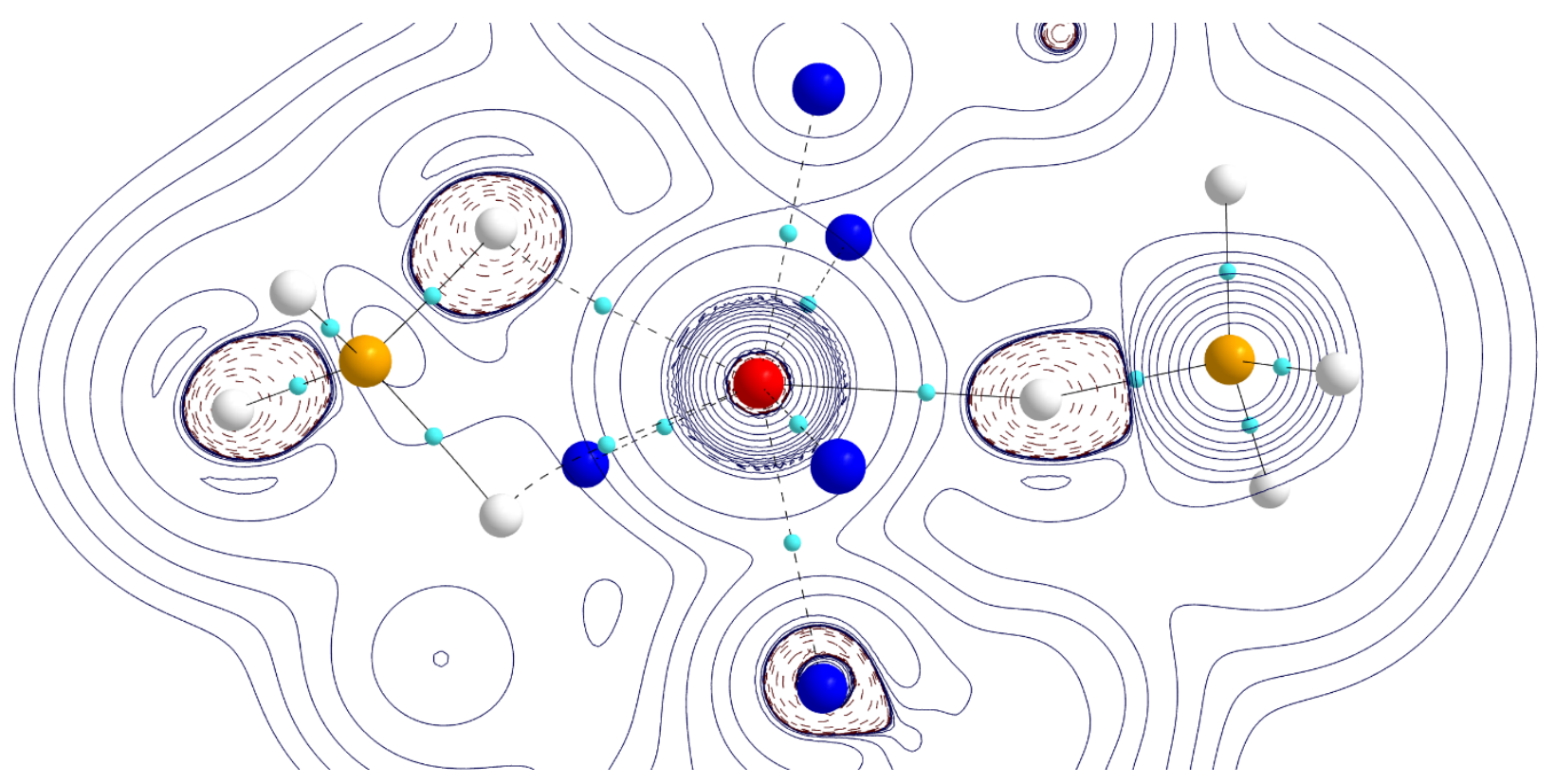

Fig. S42: Laplacian of the electron density in the plane of $[\mathrm{H} ; \mathrm{Sr} ; \mathrm{H}]$ for $\mathrm{Sr}\left(\mathrm{AlH} \mathrm{H}_{4}\right) \cdot(\mathrm{THF})_{5}$. THF omitted for clarity. 


\section{References}

[S1] Rigaku Oxford Diffraction, 2019, CrysAlisPro Software system, version 1.171.40.53, Rigaku Corporation, Oxford, UK.

[S2] O. V. Dolomanov, L. J. Bourhis, R.J. Gildea, J. A. K. Howard and H. Puschmann, J. Appl. Cryst., 2009, 42, 339341.

[S3] G. M. Sheldrick, Acta Cryst. A, 2015, 71, 3-8.

[S4] G. M. Sheldrick, Acta Cryst. C, 2015, 71, 3-8.

[S5] A. Thorn, B. Dittrich and G. M. Sheldrick, Acta Cryst. A, 2012, 68, 448-451.

[S6] Rigaku Oxford Diffraction, 2015, CrysAlisPro Software system, version 1.171.38.46, Rigaku Corporation, Oxford, UK.

[S7] Rigaku Oxford Diffraction, 2018, CrysAlisPro Software system, version 1.171.40.18b, Rigaku Corporation, Oxford, UK.

[S8] Rigaku Oxford Diffraction, 2018, CrysAlisPro Software system, version 1.171.39.46, Rigaku Corporation, Oxford, UK.

[S9] M. J. Frisch, G. W. Trucks, H. B. Schlegel, G. E. Scuseria, M. A. Robb, J. R. Cheeseman, G. Scalmani, V. Barone, G. A. Petersson, H. Nakatsuji, X. Li, M. Caricato, A. V. Marenich, J. Bloino, B. G. Janesko, R. Gomperts, B. Mennucci, H. P. Hratchian, J. V. Ortiz, A. F. Izmaylov, J. L. Sonnenberg, D. Williams-Young, F. Ding, F. Lipparini, F. Egidi, J. Goings, B. Peng, A. Petrone, T. Henderson, D. Ranasinghe, V. G. Zakrzewski, J. Gao, N. Rega, G. Zheng, W. Liang, M. Hada, M. Ehara, K. Toyota, R. Fukuda, J. Hasegawa, M. Ishida, T. Nakajima, Y. Honda, O. Kitao, H. Nakai, T. Vreven, K. Throssell, J. A. Montgomery, J. E. Peralta, F. Ogliaro, M. J. Bearpark, J. J. Heyd, E. N. Brothers, K. N. Kudin, V. N. Staroverov, T. A. Keith, R. Kobayashi, J. Normand, K. Raghavachari, A. P. Rendell, J. C. Burant, S. S. Iyengar, J. Tomasi, M. Cossi, J. M. Millam, M. Klene, C. Adamo, R. Cammi, J. W. Ochterski, R. L. Martin, K. Morokuma, O. Farkas, J. B. Foresman, D. J. Fox, Gaussian 16 Rev. A.03, Wallingford CT, 2016.

[S10] A. D. Becke, J. Chem. Phys. 1993, 98, 1372-1377.

[S11] J. P. Perdew, Electronic Structure of Solids, Akademie Verlang, Berlin, 1991.

[S12] F. Weigend, R. Ahlrichs, Phys. Chem. Chem. Phys. 2005, 3297-3305.

[S13] A. E. Reed, R. B. Weinstock, F. Weinhold, J. Chem. Phys. 1985, 83, 735-746.

[S14] R. F. W. Bader, Chem. Rev. 1991, 91, 893-928.

[S15] T. A. Keith, AIMAll (Version 17.01.25), TK Gristmill Software, Overland Park KS USA, 2017. 